WIDER Working Paper 2017/34

Variation in structural change around the world, 1985-2015

Patterns, causes, and implications

Adrian Wood*

February 2017 
Abstract: During 1985-2015, globalization intensified the factor-endowment-related pattern of sectoral specialization. In skill-abundant developed countries, manufacturing became more skillintensive. In land-scarce developing East Asia, labour-intensive manufacturing expanded, especially in China. In land-abundant developing regions, however, manufacturing stagnated or declined, while in land-scarce South Asia manufacturing was held back by low literacy and weak infrastructure. The shares of service sectors in output and employment increased in most countries, but mainly for reasons unrelated to globalization. Changes in sectoral structure in the decades ahead are subject to much uncertainty, but will continue to be shaped by differences among countries in land abundance and skill supplies.

Keywords: structural change, industrialization, globalization, Heckscher-Ohlin, factor endowments, world economy

JEL classification: F11, F14, F63, O14, O19, O57

Acknowledgements: I am indebted to Joerg Mayer for valuable comments and suggestions, and for assistance with the export data. Nobuya Haraguchi, Charles Cheng, and Eveline Smeets generously let me use their employment data. Valuable comments were provided also by Tony Addison, Ingo Borchert, Doug Gollin, Nobuya Haraguchi, and participants in seminars at the University of Sussex, Peking University, and the Development Research Centre of the State Council of China.

\footnotetext{
* Oxford University Department of International Development, adrian.wood@qeh.ox.ac.uk.
}

This paper was prepared for the UNU-WIDER 30th Anniversary Conference on 'Mapping the Future of Development Economics', held 17-19 September 2015 in Helsinki, Finland, as part of the UNU-WIDER project on 'Development policy and practicescompeting paradigms and approaches'.

Copyright (C) UNU-WIDER 2017

Information and requests: publications@wider.unu.edu

ISSN 1798-7237 ISBN 978-92-9256-258-8

Typescript prepared by Luke Finley.

The United Nations University World Institute for Development Economics Research provides economic analysis and policy advice with the aim of promoting sustainable and equitable development. The Institute began operations in 1985 in Helsinki, Finland, as the first research and training centre of the United Nations University. Today it is a unique blend of think tank, research institute, and UN agency — providing a range of services from policy advice to governments as well as freely available original research.

The Institute is funded through income from an endowment fund with additional contributions to its work programme from Denmark, Finland, Sweden, and the United Kingdom.

Katajanokanlaituri 6 B, 00160 Helsinki, Finland

The views expressed in this paper are those of the author(s), and do not necessarily reflect the views of the Institute or the United Nations University, nor the programme/project donors. 
Between 1985 and 2015, the world moved closer to being a single integrated market economy. The driving force was globalization: reductions in the costs of trade and other international transactions as a result of lowered policy barriers, better transport infrastructure, and advances in information technology. Globalization's effects were reinforced by greater use of markets, especially in the initially centrally planned economies where a third of the world's population lived, but also in other countries through deregulation and privatization.

China becoming the world's largest exporter is the most obvious outcome of globalization. But almost every country was affected to some degree, and as a result the entire structure of the world economy altered in significant respects, though there were also basic continuities. This paper describes and explains both the continuities and the changes in broad sectoral structure, drawing on one particular strand of economic theory as well as on empirical evidence.

Section 2 outlines the theory. Sections 3-6 analyse statistically how the sectoral structures of exports, output, and employment of regions and countries evolved over the period in relation to their factor endowments. Section 7 provides an explanation of the pattern of structural change, and section 8 of changes in factor prices. Section 9 concludes by discussing how the structure of the world economy might evolve over the next few decades and the implications for policies to accelerate development.

\section{Augmented Heckscher-Ohlin}

Heckscher-Ohlin (HO) theory is based on a simple idea. The mix of goods that people want to consume varies less among countries than the mix of goods that can be cheaply produced with locally available resources (or 'factors'). Countries thus tend to export goods whose production makes intensive use of factors of which they have a relatively large supply, and to import goods which require large inputs of factors that are locally scarce. HO theory has been formalized in ways that people find implausible and failed some early statistical tests. More recent and better-specified tests, however, have confirmed its empirical relevance. ${ }^{1}$

What makes HO theory useful for the analysis of globalization is that it predicts what happens to countries when barriers to trade fall. Their production and employment structures tend to become more specialized in sectors in which their factor endowments give them a comparative (production cost) advantage; and the earnings of their abundant factors tend to rise, relative to those of their scarce factors. The outcomes in any country thus depend on the composition of its factor endowments, which varies widely among countries.

The effects of reduction of trade costs depend also on determinants of trade omitted from HO theory, such as economies of scale and 'Ricardian' differences among countries in the relative technical efficiency of different sectors. Moreover, there is more to globalization than the reduction of trade costs on which HO focuses. Also important is reduction of 'co-operation costs': improved travel and communications facilities gave developing countries better access to technical,

\footnotetext{
${ }^{1}$ For a review, see Wood (2009), as well as Romalis (2004), Chor (2010), and Rotunno and Wood (2016).
} 
marketing, and managerial know-how from developed countries, enabling them to export goods that they could not otherwise have made or sold (Anderson et al. 2006).

These transfers of know-how were concentrated on certain sectors and so had some Ricardian effects on sectoral structure and factor prices. Motivated by opportunities for profit, however, the transfers were mainly to sectors in which the endowments of the country concerned already gave it a comparative advantage - sometimes in primary products such as out-of-season fruit, but more often in labour-intensive manufacturing - tending to reinforce $\mathrm{HO}$ determinants of sectoral structures. The combination of reductions in trade costs and in co-operation costs also caused fragmentation of manufacturing, with more trade in components, and the emergence of global value chains (WTO 2014, part IIC).

The various effects of globalization can thus be analysed in an 'augmented' HO model. This model can also accommodate the effects of forces other than globalization, including increased incomes, which altered the composition of demand, and exogenous changes in technology.

\section{Regional factor endowments}

Comparative advantage in $\mathrm{HO}$ theory depends on endowments of internationally immobile factors, of which three broad types will be distinguished: land (natural resources), skill (human capital), and labour. Non-human capital remains in the background because it is now highly mobile internationally, in both its financial form and its physical form (machinery), making it unusual for the sectoral structures of countries to be powerfully influenced by fixed national 'endowments' of capital (Wood 1994: 32-40). If a country has a comparative advantage in a good because of the abundance of an immobile factor, plus access to the necessary know-how, it can usually get the required capital, either domestically or from abroad.

Non-human capital is of course vital for growth, and it undoubtedly has effects also on sectoral structure. Goods vary in capital intensity, and some developing countries are poorly integrated into world capital markets. But the main differences in factor intensity among the sectors that are distinguished in the present analysis - primary, more and less skill-intensive manufacturing, and services - are in their use of land, skill, and labour, rather than of capital. Moreover, neither the continuities nor the changes in sectoral structure to be described below seem likely to have been much influenced by variation among countries in endowments of immobile capital, with the important exception of infrastructure.

One key dimension of endowment mix is the land/labour ratio, to be measured by a country's total land area divided by its adult (over-15) population. Land area is evidently not an ideal measure of natural resource availability, since it fails to allow for variation among countries in the quality of their land. But it is an unbiased measure, because what each country has, per square kilometre of its surface area, in terms of soil fertility, water resources, minerals, and so on, can be seen as the outcome of a random draw, and it is more plausibly exogenous than other measures of natural resources, such as arable land and mineral reserves.

Another key dimension of a country's endowment mix is the skill/labour ratio, to be measured by the average years of schooling of its adult population (and its endowment of skill as its total number of person-years of schooling). Years of schooling is again far from an ideal measure of skill, since it fails to allow for differences among countries and over time both in how much is learned in school and in skills acquired outside school. It is the best available measure for worldwide analysis over a long period, but has to be interpreted cautiously. 
The empirical analysis in this paper is limited to countries whose total populations exceeded 1 million in 1990, of which at the end of the period there were about 150, containing $99 \%$ of the world's population. During the period, some countries split up, most notably the USSR and Yugoslavia, or united. To make comparisons between the start and end of the period, the data for the countries involved are added together - for example, combining East and West Germany in 1985 and the constituent states of the former USSR in 2015. The resulting 130 countries are listed in the statistical Appendix.

Countries are grouped into ten regions. The seven developing regions closely follow the World Bank's classification: two in East Asia (separating China from Other East Asia), two in South Asia (India and Other South Asia), Latin America, Sub-Saharan Africa, and the Middle East and North Africa (MENA). The Former Soviet Sphere (FSS) includes the USSR and Eastern Europe. The OECD is split into two regions, separating the land-scarce countries of Western Europe and Japan from the land-abundant ones of North America, Australia, New Zealand, and Scandinavia. To avoid end-period selection bias, the country composition of all regions is as it was in 1985 (for example, the OECD excludes Korea and Poland). All the regional variables in this paper are aggregates, based on addition across countries, and so are more influenced by the larger countries in each region (though only in one region does a single country account for over half the total population: the US is four-fifths of the land-abundant OECD). ${ }^{2}$

Figure 1 shows regional endowment ratios in 1985. The regions divide horizontally into two groups of widely differing land abundance - five clustered around an average of about $1.5 \mathrm{~km}^{2}$ of land per 100 adults and the other five around an average of about $9 \mathrm{~km}^{2}$. Within each group there is a vertical hierarchy of skill abundance, with average years of schooling rising from under 3 at the bottom of each group to 12 in the land-abundant OECD. The endowments of the regions in 1985 thus varied widely, though there was far wider variation among individual countries, whose land/labour ratios ranged from near zero in Hong Kong to 140 in Mongolia and average years of schooling from 0.6 in Yemen to 12.0 in the United States.

Figure 2 shows how regional endowments changed between 1985 and 2010 (the latest year for schooling data): the endowments of each region in each year are expressed as a logged ratio of the world average (because comparative advantage depends on one's endowments compared to those of others). In 2010, all the regions were in roughly the same relative positions as at the start of the period - much as they had been back to at least 1950 - though slower population growth in richer than in poorer regions caused their relative land abundance to move in opposite directions, and poorer regions became relatively more schooled.

\footnotetext{
${ }^{2}$ The former USSR accounts for more than half the population of the FSS, but Russia for only one-third. The biggest population shares in other regions in 2015 are Pakistan (44\% of Other South Asia), Indonesia (34\% of Other East Asia), Brazil (33\% of Latin America), Japan (24\% of the land-scarce OECD), Egypt (18\% of MENA), and Nigeria (18\% of Sub-Saharan Africa). Regional aggregate shares or ratios (e.g. the share of manufacturing in GDP in Latin America) can be interpreted as weighted averages of the shares or ratios in the countries of the region, but with weights (relative country sizes) that differ among variables. For example, sectoral shares of GDP are weighted by a country's GDP, but sectoral shares of exports by the total value of its exports.
} 
Figure 1: Regional endowment ratios, 1985

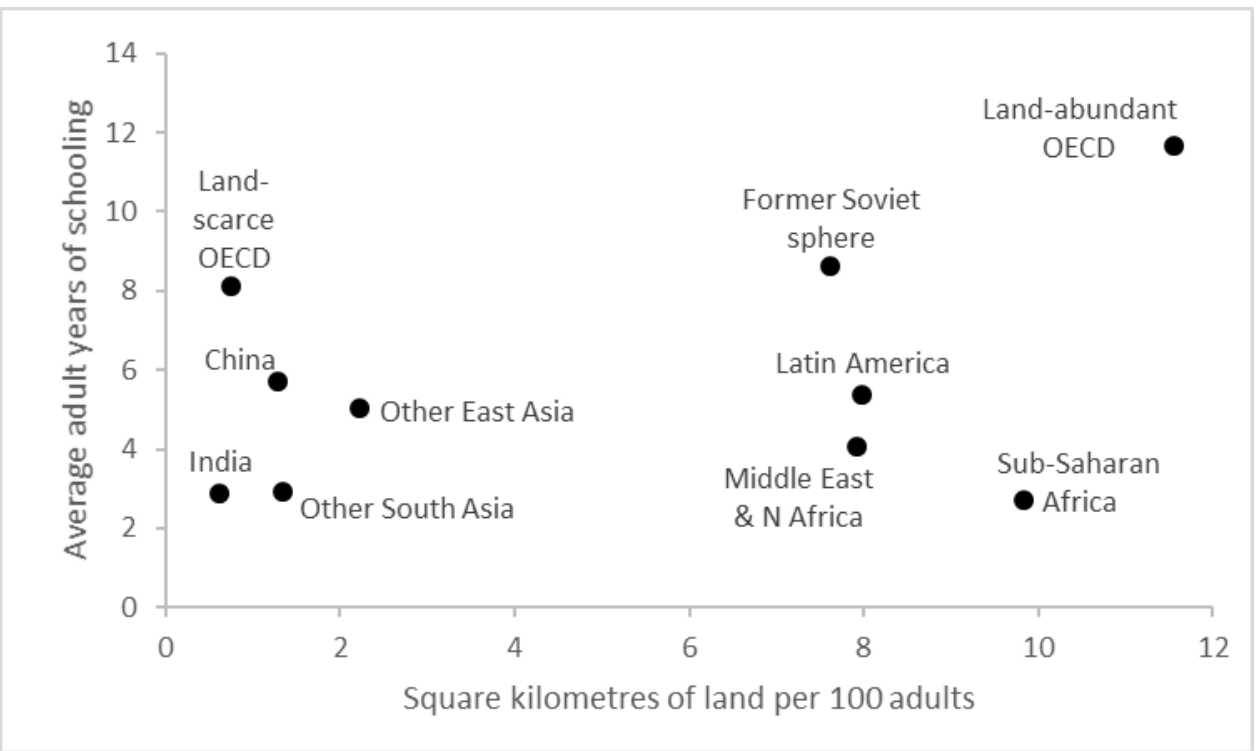

Notes: adults are over 15; land area from World Development Indicators; schooling from Barro and Lee dataset v. 2.1 (gaps for nine countries filled using UNESCO data on adult literacy).

Figure 2: Changes in regional endowment ratios, 1985-2010

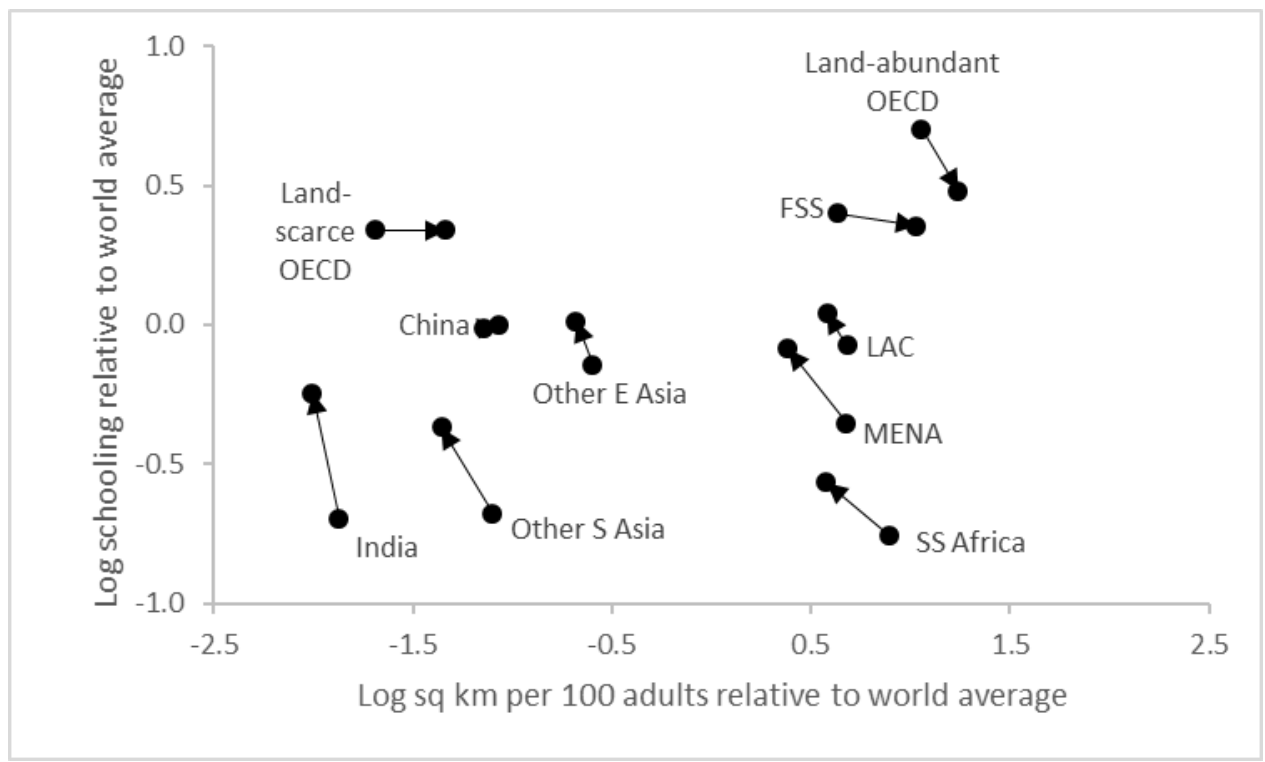

Notes: sources as for figure 1. Average adult years of schooling and land area per adult in each region and year are logged ratios of world (weighted) averages in the year concerned. 'LAC' = Latin American and Caribbean countries.

The schooling changes, however, are misleading: increased enrolments in poorer regions were associated with a fall in the average quality of schooling, so there was little narrowing of the gaps in skill per worker among regions (Pritchett 2013). Some countries made real educational progress, but for most countries, as for regions, there was little change in relative endowments: the correlations across countries between 1985 and 2010 values are 0.94 for average years of schooling and 0.98 for land area per adult. Changes in the structure of the world economy over this period are thus unlikely to have been driven by changes in relative endowments. 
A more plausible cause of structural change is the worldwide increase in openness to trade. Figure 3 shows regional trade/GDP ratios at the start and end of the period, including services as well as goods, and measured at constant prices. As in later figures and tables, the regions are listed according to their endowments: split into two groups on the basis of land abundance, and within each group ranked in descending order of average years of schooling in 2010, with a world average below. Levels are not comparable across regions, because intra-regional trade is included and thus the ratio varies with the number of countries. For the world as a whole, the trade ratio doubled. It also rose in every region (though the large rise in FSS partly reflects the inclusion of intra-regional trade in 2015 but not in 1985).

Figure 3: Trade share of GDP at constant prices, 1985 and 2014 (\%)

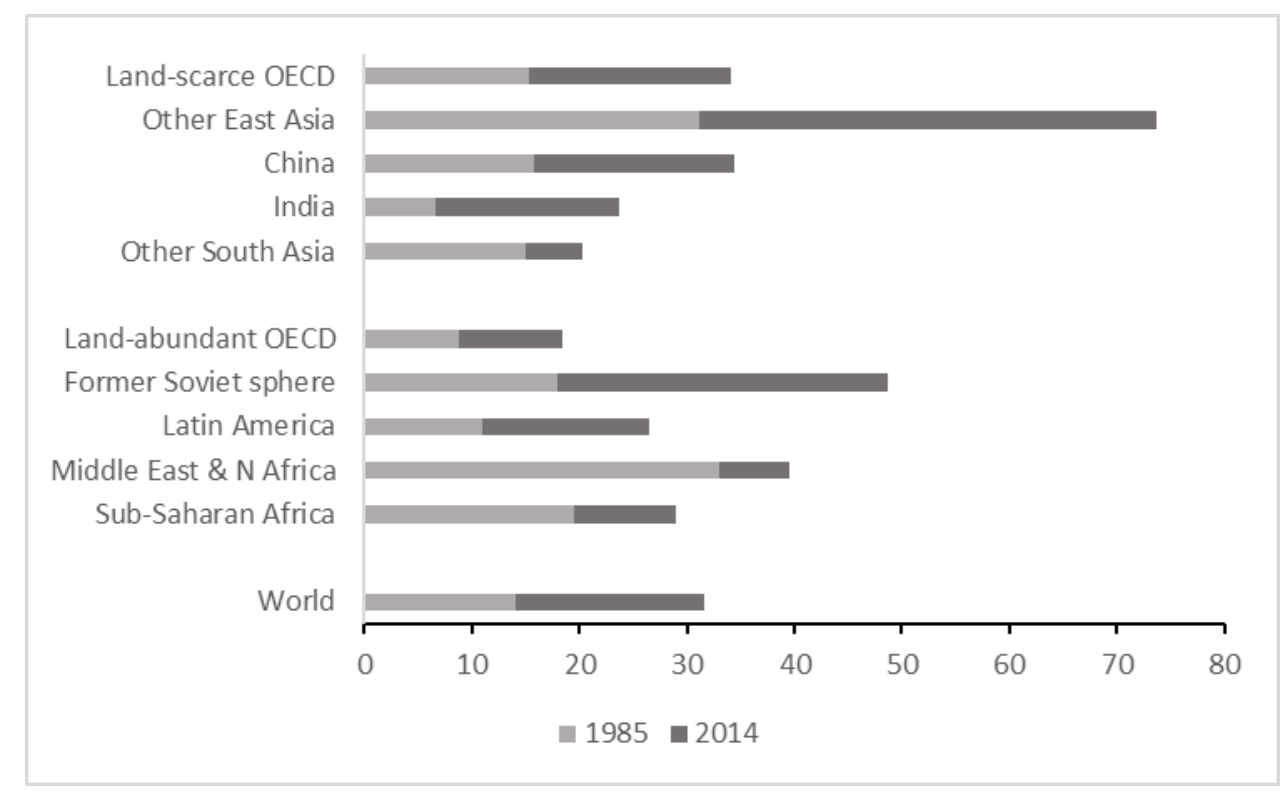

Notes: data mainly from UN National Accounts Main Aggregates database, at 2005 prices and exchange rates. 'Trade share' is the mean of the shares for exports and imports (which include both goods and services). Exports and imports include intra-regional trade (except for China, India, and in 1985 much of the FSS).

This rise in trade ratios should (in HO theory) have been accompanied by the sectoral structures of regions and countries becoming more closely aligned with their factor endowments. This and the following two sections will analyse statistically the composition of exports, output, and employment relative to endowments during this period, focusing on three aspects of structure: the ratio of primary (agriculture and mining) to manufacturing, the skill mix of manufacturing, and the ratio of services to goods (where goods are defined as primary plus manufacturing, and services as all other sectors). Section 7 will then argue that the pattern of structural change was indeed explained partly by a fall in trade costs, but also by a fall in co-operation costs.

More details of the data and methods used in the statistical analysis are in the notes to the tables and figures and in the statistical Appendix. It is worth mentioning here, though, that all of the regressions were subjected to robustness tests involving the omission of two sorts of countries: outliers in terms of skill abundance, land abundance, or size; and those in East Asia (which is commonly seen as exceptional). The tables indicate the few cases in which these tests caused coefficients to become insignificant, none of which affects any point of substance. 


\subsection{Manufactured/primary exports}

The first three columns of table 1 show the sectoral structure of exports in each region in 2014, measured by their domestic-value-added content. Manufactured exports are defined broadly, including processed primary products such as canned food and refined petroleum, to match the definition of the sector in output and employment data, rather than using the narrower definition of manufactures in most trade statistics. ${ }^{3}$

Table 1: Exports by broad sector, 2014 levels and 1985-2014 changes

\begin{tabular}{|c|c|c|c|c|c|}
\hline & \multicolumn{3}{|c|}{$\begin{array}{c}\text { Shares of total } 2014 \\
(\%)\end{array}$} & \multicolumn{2}{|c|}{$\begin{array}{l}\text { Changes 1985-2014 } \\
\text { (Percentage points) }\end{array}$} \\
\hline & Primary & $\begin{array}{l}\text { Manu- } \\
\text { factured }\end{array}$ & Services & $\begin{array}{l}\text { Manuf'd } \\
\text { /goods }\end{array}$ & $\begin{array}{r}\text { Services } \\
/ \text { total }\end{array}$ \\
\hline \multicolumn{6}{|l|}{ Land-scarce regions } \\
\hline Land-scarce OECD & 7.4 & 64.3 & 28.3 & 1.1 & 7.0 \\
\hline Other East Asia & 12.3 & 65.0 & 22.7 & 13.4 & 5.4 \\
\hline China & 2.8 & 84.6 & 12.6 & 45.5 & -2.3 \\
\hline India & 12.6 & 49.2 & 38.2 & 16.1 & 10.4 \\
\hline Other South Asia & 16.1 & 59.9 & 23.9 & 22.3 & 2.2 \\
\hline \multicolumn{6}{|l|}{ Land-abundant regions } \\
\hline Land-abundant OECD & 22.4 & 48.0 & 29.6 & -5.8 & 6.5 \\
\hline Former Soviet sphere & 29.6 & 53.8 & 16.6 & -12.5 & 4.6 \\
\hline Latin America & 43.8 & 42.2 & 14.0 & -1.1 & -3.8 \\
\hline Middle East \& N Africa & 59.2 & 29.5 & 11.3 & -10.8 & -1.0 \\
\hline Sub-Saharan Africa & 59.3 & 25.4 & 15.2 & -14.2 & 3.4 \\
\hline World & 19.4 & 57.3 & 23.2 & -0.8 & 3.6 \\
\hline
\end{tabular}

Notes: exports measured in terms of domestic-value-added content. Primary is agriculture plus mining. ISIC (International Standard Industrial Classification) rather than SITC (Standard International Trade Classification) definitions of manufactures and primary. Data on merchandise exports from UNCTAD database, on service exports from World Trade Organization (WTO) database, and on value-added content from OECD/WTO TiVA database. Further details of sources and calculations are in the statistical Appendix.

The export share of primary products is consistently larger in the land-abundant regions than in the land-scarce regions, as $\mathrm{HO}$ theory and common sense predict, since the primary sectors are more land-intensive than other sectors. ${ }^{4}$ Figure 4 plots each region's manufactured/primary export ratio against its skill/land endowment ratio, to allow for the fact that manufacturing is both more skill-intensive and less land-intensive than primary production. ${ }^{5}$ The corresponding cross-country regression line is shown, too, and has a steep upward slope. It fits the data fairly well, but China's manufactured/primary export ratio is far higher than would be predicted for a country with its skill/land ratio.

\footnotetext{
${ }^{3}$ The focus here on the structure of exports neglects the structure of imports, which in theory is just as important but in practice is less strongly related to endowments (Owens and Wood 1997: 1464-65).

${ }^{4}$ This is obvious for agriculture. Mines usually occupy small areas of land, but they depend on the existence of large mineral reserves, for the probability of which the land area of the country concerned is a proxy.

${ }^{5}$ The difference in skill intensity is documented in section A of the statistical Appendix.
} 
Figure 4: Manufactured/primary exports and skill/land endowments, 2014

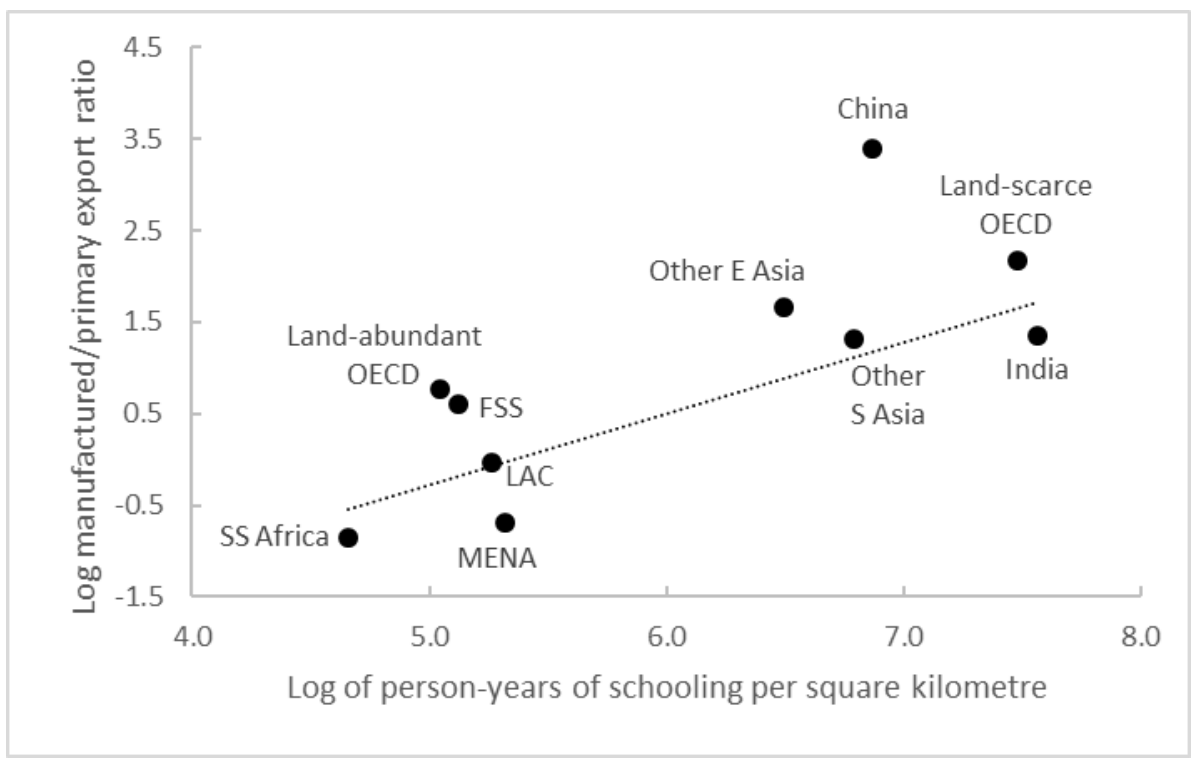

Notes: data on endowments (in 2010) as for figures 1-2, and on exports as for table 1. Regional averages are of exports on a domestic-value-added basis. Regression line shows relationship across countries rather than across regions, with exports measured gross: its slope is 0.78 and its $R$-squared is 0.45 . (Across regions, the slope is 0.93 and the R-squared 0.60.)

That manufactured/primary export ratios depend both on skill/labour endowment ratios and on land/labour endowment ratios is confirmed by the first two regressions in panel A of table 2: there is a positive coefficient on years of schooling and a negative coefficient on land per adult, both in 1985 and in 2014. In both years, there is also a positive coefficient on population size: for any given endowment mix, larger countries tend to export more manufactures. The export structures of countries became more closely aligned with their endowments over this period, since R-squared is higher in 2014 than in 1985.

Between 1985 and 2014, the share of manufactures in exports of goods rose in each of the landscarce regions and fell in each of the land-abundant regions (table 1, fourth column), matching the difference in their endowment-based comparative advantage. ${ }^{6}$ At constant prices, all the changes would look more positive for manufactures, because the world price of manufactures relative to that of primary products fell by about 30\% during $1985-2015 .^{7}$ But the relative sizes of the changes in the different regions would remain largely the same.

Across countries, too, changes in the manufactured/primary export ratio were inversely related to levels of land abundance, as shown in the third regression in panel A of table $2 .{ }^{8}$ There is also a big drop in the land coefficient between the 1985 and 2014 regressions, suggesting an increase in the comparative disadvantage of land-abundant countries in manufactured exports. The rise in the schooling coefficient between 1985 and 2014, however, probably reflects only the misleading shrinkage of cross-country educational gaps mentioned earlier.

\footnotetext{
${ }^{6}$ If table 1 were calculated with gross export data, the signs of these manufactured export share changes would be the same, except that the small decrease $(-1.1)$ in Latin America would be a small increase $(+1.4)$.

${ }^{7}$ Calculation based on export unit values derived from WTO (2015, table A.1).

${ }^{8}$ Changes in the export ratio were completely unrelated to changes in endowments.
} 
Table 2: Sectoral export ratios regressed on endowment ratios

\begin{tabular}{|c|c|c|c|c|}
\hline \multirow[b]{2}{*}{$\begin{array}{l}\text { Dependent variable \& } \\
\text { specification }\end{array}$} & \multicolumn{3}{|c|}{ Coefficients on independent variables } & \multirow[b]{2}{*}{ R-squared } \\
\hline & $\begin{array}{l}\text { Av. adult yrs of } \\
\text { schooling }\end{array}$ & $\begin{array}{l}\text { Square } \mathrm{km} \text { of } \\
\text { land per adult }\end{array}$ & $\begin{array}{l}\text { Adult }(15+) \\
\text { population }\end{array}$ & \\
\hline \multicolumn{5}{|l|}{ A. Manufactured/primary } \\
\hline 1985 levels & 1.02 & -0.33 & 0.23 & 0.43 \\
\hline 2014 levels & 1.59 & -0.58 & $\{0.22\}$ & 0.53 \\
\hline Change on 1985 level & {$[-0.07]$} & -0.27 & {$[-0.03]$} & 0.11 \\
\hline \multicolumn{5}{|c|}{ B. Processed primary/narrow manufactures } \\
\hline 1985 levels & $\{-0.40\}$ & 0.45 & {$[-0.03]$} & 0.27 \\
\hline 2014 levels & $\{-0.54\}$ & 0.48 & {$[-0.09]$} & 0.31 \\
\hline Change on 1985 level & {$[0.26]$} & {$[0.04]$} & {$[-0.06]$} & 0.02 \\
\hline \multicolumn{5}{|c|}{ C. Processed primary/unprocessed primary } \\
\hline 1985 levels & 0.82 & [0.04] & 0.22 & 0.26 \\
\hline 2014 levels & 1.36 & -0.25 & $\{0.15\}$ & 0.32 \\
\hline Change on 1985 level & {$[0.13]$} & -0.24 & {$[-0.03]$} & 0.09 \\
\hline \multicolumn{5}{|c|}{ D. Skill-intensive/labour-intensive narrow manufactures } \\
\hline 1985 levels & 1.36 & {$[0.05]$} & [0.01] & 0.24 \\
\hline 2014 levels & 2.94 & [0.09] & [0.02] & 0.45 \\
\hline Change on 1985 level & 0.68 & {$[-0.00]$} & [0.08] & 0.12 \\
\hline \multicolumn{5}{|c|}{ E. Services/goods (manufactured plus primary) } \\
\hline 1985 levels & {$[-0.10]$} & -0.19 & {$[-0.03]$} & 0.06 \\
\hline 2014 levels & {$[-0.11]$} & -0.26 & {$[-0.11]$} & 0.12 \\
\hline Change on 1985 level & {$[-0.02]$} & {$[-0.09]$} & {$[-0.06]$} & 0.02 \\
\hline
\end{tabular}

Notes:

1. Data as for figures 1-2 and tables 1 and 3. Exports measured gross, not by domestic-value-added content. All variables in natural logs.

2. OLS cross-section regressions on 119 countries with data in both 1985 and 2014 (except, in panel D, on 82 countries where narrow manufactures $\geq 10 \%$ of total exports in both years).

3. '1985 levels' = 1985 exports on 1985 endowments; '2014 levels' = 2014 exports on 2010 endowments; 'Change on 1985 level' = 1985-2014 change in exports on 1985 endowments.

4. Coefficients are significant at $10 \%$ level or better unless in square brackets. Those in chain brackets become insignificant in one or other of two robustness checks: (i) omission of all East Asian countries; (ii) omission of countries with outlying values of independent variables: nine with very low schooling (Burkina Faso, Ethiopia, Guinea, Guinea-Bissau, Mali, Mozambique, Niger, Senegal, and Yemen), two with very low land per worker (Hong Kong and Singapore), and three with very large populations (China and India, plus the USSR, which in 2014 is an artificial aggregate of its constituent countries). 
Table 3: Manufactured export composition, 2014 levels and 1985-2014 changes

\begin{tabular}{|c|c|c|c|c|c|}
\hline & \multicolumn{3}{|c|}{$\begin{array}{c}\text { Shares } 2014 \\
(\%)\end{array}$} & \multicolumn{2}{|c|}{$\begin{array}{l}\text { Changes 1985-2014 } \\
\text { (Percentage points) }\end{array}$} \\
\hline & $\begin{array}{r}\text { Processed } \\
\text { primary/ } \\
\text { all mfs }\end{array}$ & $\begin{array}{r}\text { Skill- } \\
\text { intensive/ } \\
\text { all mfs }\end{array}$ & $\begin{array}{r}\text { Skill- } \\
\text { intensive/ } \\
\text { narrow mfs }\end{array}$ & $\begin{array}{r}\text { Processed } \\
\text { primary/ } \\
\text { all mfs }\end{array}$ & $\begin{array}{r}\text { Skill- } \\
\text { intensive/ } \\
\text { narrow mfs }\end{array}$ \\
\hline \multicolumn{6}{|l|}{ Land-scarce regions } \\
\hline Land-scarce OECD & 12.2 & 66.0 & 75.2 & 0.2 & 9.4 \\
\hline Other East Asia & 13.6 & 58.0 & 67.1 & -2.5 & 31.4 \\
\hline China & 3.8 & 19.4 & 20.2 & -14.6 & 6.4 \\
\hline India & 26.9 & 26.7 & 36.5 & 14.6 & 22.4 \\
\hline Other South Asia & 4.0 & 4.7 & 4.9 & -6.7 & -3.0 \\
\hline \multicolumn{6}{|l|}{ Land-abundant regions } \\
\hline Land-abundant OECD & 19.4 & 62.0 & 77.0 & 3.5 & 2.7 \\
\hline Former Soviet sphere & 27.1 & 44.7 & 61.3 & 5.1 & 1.1 \\
\hline Latin America & 22.2 & 37.5 & 48.2 & -18.3 & 9.2 \\
\hline Middle East \& N Africa & 32.2 & 33.3 & 49.1 & -3.5 & 4.6 \\
\hline Sub-Saharan Africa & 47.0 & 26.0 & 49.1 & 1.1 & 16.9 \\
\hline World & 15.0 & 51.8 & 60.9 & -1.9 & -0.9 \\
\hline
\end{tabular}

Notes: Data on exports, measured gross, from UNCTAD database. Processed primary exports make up the difference between the broad ISIC definition of manufactures used in this paper and the narrow SITC definition of manufactured exports. The division of narrow manufactured exports into skill-intensive and (unskilled) labourintensive items is specified in the statistical Appendix. It follows Wood and Mayer (2011), and is based mainly on reviews of studies that ranked industries by their skilled labour shares or other measures of skill intensity near the start of the period covered by the present analysis (including Wood 1994, ch. 3).

\subsection{Composition of manufactured exports}

Manufactured exports can be divided between processed primary products and 'narrow' (SITC definition) manufactures. Processed primary products are more land-intensive, so their share of manufactured exports tends to be higher in land-abundant than in land-scarce regions (first column of table 3: the high share in India misleadingly arises from refining of imported oil - exports in this table are measured gross rather than by domestic value added). The same is true of countries, as shown by the positive coefficients on land per adult in the first two regressions in panel B of table 2. There is no clear difference in skill intensity between processed primary products and narrow manufactures.?

Processed primary exports are, however, clearly more skill-intensive than unprocessed primary exports: the positive schooling coefficients in the first two regressions in panel $\mathrm{C}$ of table 2 are consistent with data on education by sector in almost all countries (in the statistical Appendix). In 1985 the processed/unprocessed primary export ratio was unrelated to land abundance, but by 2014 the relationship had become negative, and the 1985-2014 change in this export ratio is inversely related to land abundance. This emergence of comparative disadvantage for land-

\footnotetext{
${ }^{9}$ The negative schooling coefficients in panel B of table 2 imply that primary processing is less skill-intensive than narrow manufacturing, but are not robust, and this is not the case in about one-third of countries, as shown by the data on education by sector in section A of the statistical Appendix.
} 
abundant countries in primary processing parallels (in direction and size) the worsening of their comparative disadvantage in all manufacturing implied by the regressions in panel A.

On the basis of the skilled share of employment in each industry, narrow manufactured exports are divided between skill-intensive goods such as aircraft and chemicals and (unskilled) labourintensive goods such as garments and steel. In each land-abundance group, the skill-intensive shares of manufactured exports tend to rise across regions with their skill/labour endowment ratios (table 3, third column). This HO relationship across regions is shown explicitly in figure 5, which also includes the corresponding cross-country regression line. Two regional outliers are SubSaharan Africa, distorted upwards by South Africa, and Other South Asia, whose skill-intensive manufactured export share is much lower than that of India. ${ }^{10}$

Figure 5: Skill intensity of manufactured exports and skill/labour endowments, 2014

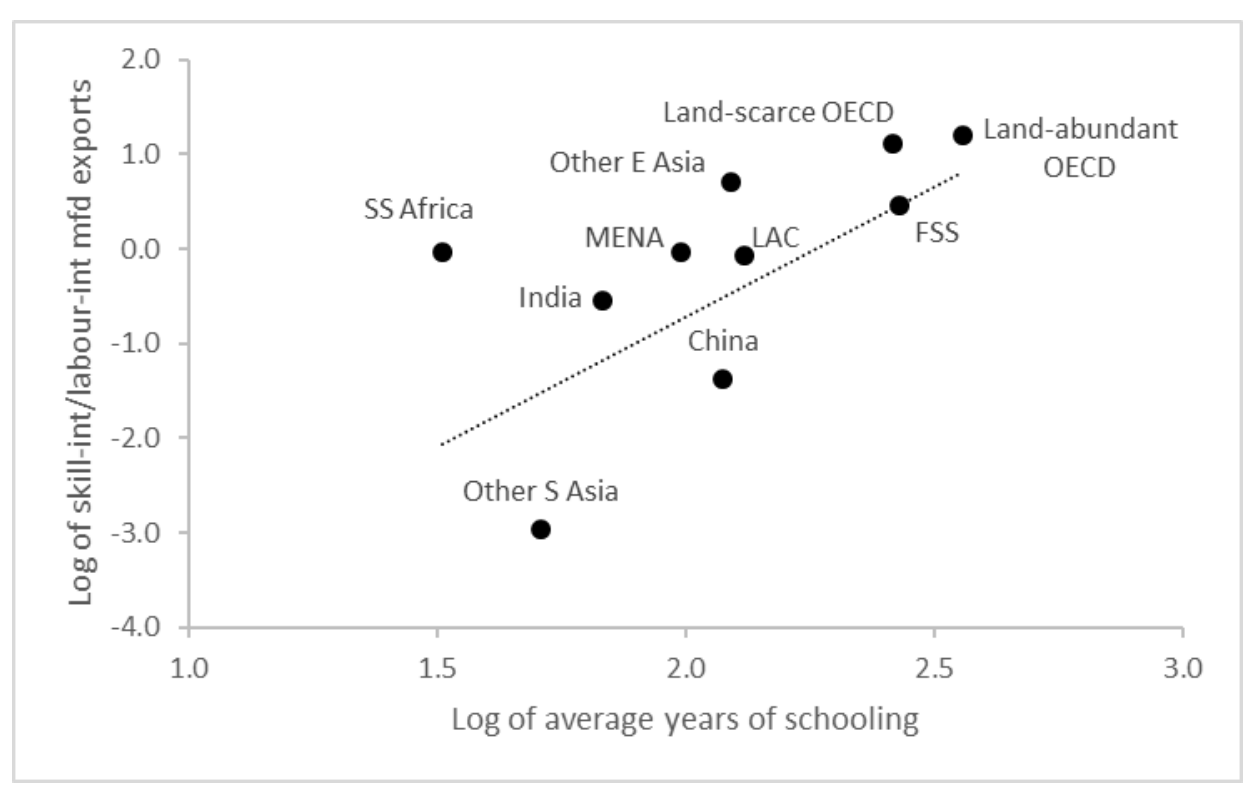

Notes: data on endowments (in 2010) as for figures 1-2, and on exports as for table 3 . Regression line shows relationship across countries where narrow manufactures are $10 \%$ or more of total exports. Its slope is 2.74 and its $\mathrm{R}$-squared is 0.42 . (Across regional points in the figure, the slope is 2.38 and the R-squared is 0.40 .)

The determinants of the skill-intensive share of narrow manufactures are analysed more closely in panel $\mathrm{D}$ of table 2 . Schooling is the only significant explanatory variable: land intensity is much the same for these two sorts of manufacturing, and nor does their export ratio vary with country size. The fit of the regressions improved substantially over the period, indicating that in this dimension, too, export structure became more closely aligned with endowments.

The rise in the schooling coefficient between 1985 and 2014 is partly misleading, for reasons already mentioned, but is far larger than in the other export regressions. The last regression in panel D, moreover, shows changes in the skill-intensive share of narrow manufactures to have been positively related across countries to their level of schooling, implying a strengthening of the comparative advantage of more educated countries in skill-intensive manufactures.

\footnotetext{
${ }^{10}$ The distortion arises from South Africa having a high weight in the regional export ratio (because it accounts for much of the region's narrow manufactured exports) but a low weight in regional average years of schooling (because it contains only a small fraction of the region's adult population). South Africa's own data point is much further to the right and close to the cross-country regression line.
} 
This last regression, however, has little explanatory power, and the changes across regions were diverse (table 3, last column). The skill-intensive share of narrow manufactures rose not only in the skill-abundant OECD and FSS regions, but also in every developing region except Other South Asia. For the world as a whole, though, there was almost no change in this share, as a result of the increased weight of Asian regions with low shares, especially China.

One reason for this diversity is that the statistical division between skill-intensive and labourintensive goods became ever more inaccurate. Skill-intensive and labour-intensive varieties of each good, and (with the increasing role of value chains) skill-intensive and labour-intensive stages of production of the same varieties, were increasingly divided among countries in ways that cannot be measured with the available data. ${ }^{11}$ Countries thus became more specialized in manufacturing activities of differing skill intensity according to their skill endowments than the present calculations suggest.

\subsection{Services/goods exports}

The share of services in exports tends to be lower in land-abundant regions than in land-scarce regions (table 1), because services are on average less land-intensive than goods (particularly primary products). The same is true across countries, as shown by the negative coefficients on the land variable in the first two regressions in panel $\mathrm{E}$ of table 2 . The schooling coefficients are insignificant, implying that on average the skill intensity of traded services is similar to that of goods (though in both cases very varied). ${ }^{12}$ Among the land-scarce regions, the service share of exports is unusually low in China, perhaps because less foreign contact has been permitted in its service sectors than in manufacturing, and unusually high in India, reflecting the country's great success as an exporter of ICT services for largely sector-specific reasons.

The share of services in exports rose for the world as a whole during 1985-2014, but only by 4 percentage points (final column of table 1). It also rose in seven of the ten regions, again mainly by small amounts, but more substantially in both OECD regions ( 7 percentage points) and most of all in India (10 percentage points). The apparent lack of pattern in these regional changes is consistent with the last regression in panel $\mathrm{E}$ of table 2: across countries, changes in the service share of exports were unrelated to endowments and country size.

\section{$5 \quad$ Sectoral structure of output}

Table 4 shows the broad sectoral structure of GDP in each region in 2014 and how it changed during 1985-2014.

\footnotetext{
${ }^{11}$ Section A of the statistical Appendix shows that in 14 European countries even by 2000 the educational level of 'skill-intensive' manufacturing sectors was equal to or lower than that of 'labour-intensive' sectors. To allow for fragmentation, exports of computers and office and communications equipment (SITC 75-77) are categorised as skillintensive in more educated countries and labour-intensive in less educated countries.

${ }^{12}$ Services in total, including both traded and non-traded services, are on average more skill-intensive than goods, as discussed later and documented in section A of the statistical Appendix.
} 
Table 4: Output by broad sector, 2014 levels and 1985-2014 changes

\begin{tabular}{|c|c|c|c|c|c|c|}
\hline & \multicolumn{3}{|c|}{$\begin{array}{c}\text { Shares of GDP } 2014 \\
(\%)\end{array}$} & \multicolumn{3}{|c|}{$\begin{array}{l}\text { Changes 1985-2014 } \\
\text { (Percentage points) }\end{array}$} \\
\hline & Primary & $\begin{array}{r}\text { Manu- } \\
\text { facturing }\end{array}$ & Services & $\begin{array}{l}\text { Manuf'g } \\
\text { /goods }\end{array}$ & $\begin{array}{l}\text { Manuf'g } \\
\text { /GDP }\end{array}$ & $\begin{array}{l}\text { Services } \\
\text { /GDP }\end{array}$ \\
\hline \multicolumn{7}{|l|}{ Land-scarce regions } \\
\hline Land-scarce OECD & 2.4 & 16.0 & 81.5 & 4.5 & -7.9 & 10.6 \\
\hline Other East Asia & 11.0 & 23.9 & 65.1 & 14.1 & 0.8 & 7.5 \\
\hline China & 14.9 & 28.3 & 56.9 & 15.8 & -3.8 & 21.3 \\
\hline India & 20.1 & 17.2 & 62.8 & 15.0 & 1.2 & 14.1 \\
\hline Other South Asia & 22.8 & 15.3 & 62.0 & 12.8 & 2.4 & 9.1 \\
\hline \multicolumn{7}{|l|}{ Land-abundant regions } \\
\hline Land-abundant OECD & 5.0 & 11.7 & 83.2 & -8.5 & -6.9 & 7.0 \\
\hline Former Soviet sphere & 12.3 & 17.3 & 70.4 & -5.0 & -12.9 & 18.0 \\
\hline Latin America & 13.7 & 14.0 & 72.3 & -12.5 & -11.4 & 12.5 \\
\hline Middle East \& N Africa & 28.5 & 11.8 & 59.7 & -2.0 & -0.7 & -0.3 \\
\hline Sub-Saharan Africa & 29.6 & 9.9 & 60.5 & -1.5 & -1.1 & 1.9 \\
\hline World & 9.4 & 16.5 & 74.1 & -4.4 & -5.2 & 6.0 \\
\hline Developing countries & 17.2 & 20.3 & 62.5 & 8.7 & 0.1 & 7.0 \\
\hline
\end{tabular}

Notes. 'Services' is all sectors except primary (agriculture plus mining) and manufacturing. 'Developing countries' exclude both OECD regions and FSS. Data mainly from UN National Accounts Main Aggregates, supplemented with detailed data from the UN National Accounts database and other sources to split mining from 'industry'. Manufacturing share for China in 1985 adjusted using the Groningen Growth and Development Centre (GGDC) ten-sector database (because UN China data for that year refer to industry rather than to manufacturing); and manufacturing share for India in 1985 adjusted using the World Development Indicators database, whose numbers for that year are closer than the UN data to official Indian estimates. Further details of sources and calculations are in the statistical Appendix.

\subsection{Manufactured/primary output}

Within each land-abundance group, the primary share of GDP in 2014 falls across regions with their level of development, proxied by schooling. A HO relationship emerges more clearly in figure 6 , which relates the manufactured/primary output ratio to the skill/land endowment ratio. There is an upward slope across regions, as also in the cross-country regression line shown in the figure (which is somewhat less steep than for exports in figure 4). ${ }^{13}$ That this output ratio is positively related to skill abundance and negatively related to land abundance is confirmed by the cross-country regressions in the first two rows of panel A in table 5.

\footnotetext{
13 The export regression slope is steeper because the composition of domestic demand varies less among countries than that of output (and hence the composition of trade varies more). Moreover, barriers to trade make abundantfactor-intensive goods relatively cheaper in home markets, so measured variation in sectoral output value shares is smaller than it would be in terms of volume (to a greater extent than for exports, whose prices in world markets differ less among countries). However, this variation in internal prices also reduces variation in the composition of exports by inducing variation in domestic demand that absorbs part of the variation in endowments.
} 
Figure 6: Manufactured/primary output and skill/land endowments, 2014

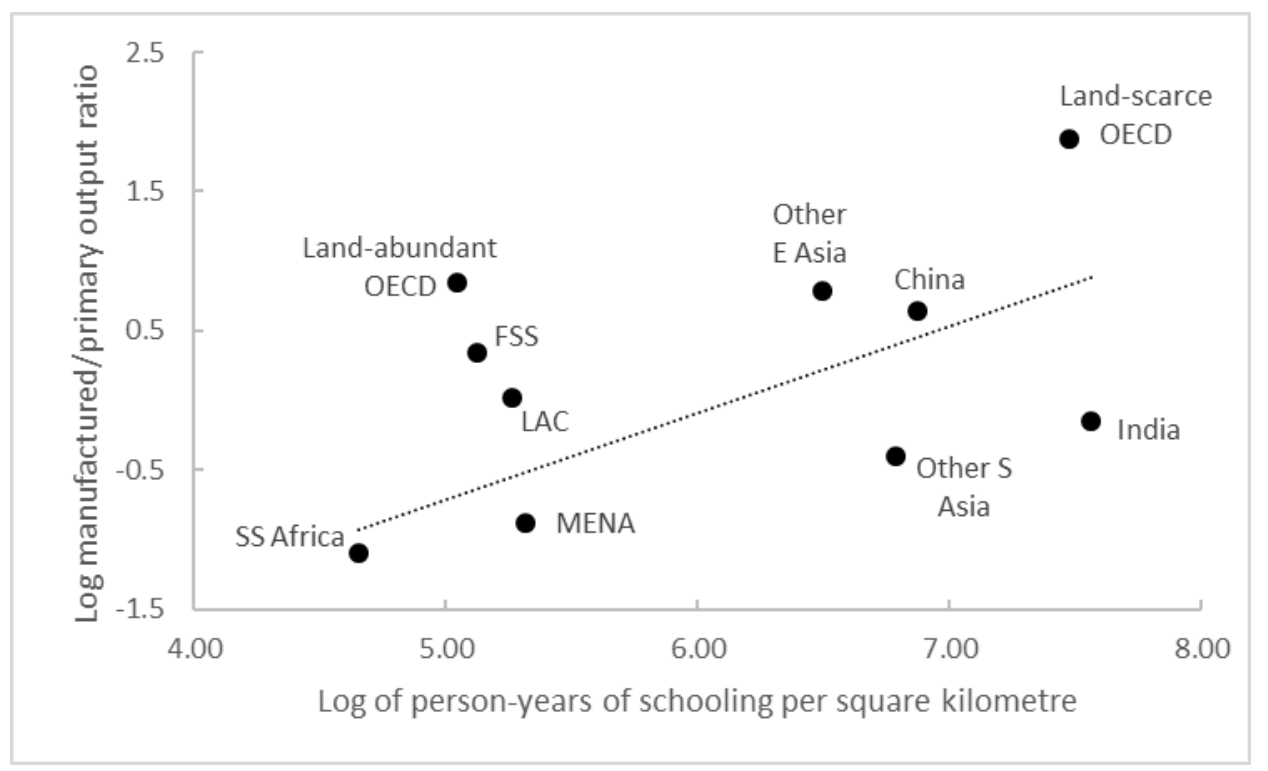

Notes: endowments (in 2010) as for figures 1-2, and output as for table 4. Regression line shows relationship across countries, not across regions. Its slope is 0.63 and its R-squared is 0.45 . (Across regions, the slope is 0.37 and the R-squared 0.21.)

In the OECD and the land-abundant regions, manufactured/primary output ratios (figure 6) are similar to the corresponding export ratios (figure 4). ${ }^{14}$ In all four Asian developing regions, though, export ratios exceed output ratios. In East Asia, and especially in China, this is because export ratios are high and output ratios normal (in relation to the cross-country regression line). In South Asia, by contrast, it is because export ratios are normal and output ratios low.

These differences between East Asia and South Asia partly reflect differences in infrastructure, trade policies, and labour laws. In addition, what makes average years of schooling higher in East Asia than in South Asia is that there are more workers with a basic education and fewer with no education. Since workers with a basic education are vital for manufacturing, especially of labourintensive products for export, this difference in schooling mix helps to explain both why East Asia's manufactured/primary export ratio is unusually high and why South Asia's manufactured/primary output ratio is unusually low.

The share of manufactures in output of goods rose during 1985-2014 in each land-scarce region and fell in each land-abundant region (table 4, fourth column) - the same pattern as for export shares. Across countries, too, changes in the manufactured/primary output ratio were inversely related to levels of land abundance, as shown by the third regression in panel A of table 5, and the 1985-2014 fall in the land coefficient in the first two regressions again suggests a deepening of the comparative disadvantage of land-abundant countries in manufacturing. R-squared does not rise, indicating that the output structures of countries became no more closely aligned with their endowments - unlike their export structures (though the output regression fits better than the corresponding export regression in both 1985 and 2014).

\footnotetext{
${ }^{14}$ Comparisons of sectoral export and output ratios are complicated by the fact that the domestic value added in (say) manufactured exports originates partly in sectors other than manufacturing (WTO 2014, figure C.11).
} 
Table 5: Sectoral output ratios regressed on endowment ratios

\begin{tabular}{|c|c|c|c|c|}
\hline \multirow[b]{2}{*}{$\begin{array}{l}\text { Dependent variable \& } \\
\text { specification }\end{array}$} & \multicolumn{3}{|c|}{ Coefficients on independent variables } & \multirow[b]{2}{*}{ R-squared } \\
\hline & $\begin{array}{l}\text { Av. adult yrs of } \\
\text { schooling }\end{array}$ & $\begin{array}{l}\text { Square } \mathrm{km} \text { of } \\
\text { land per adult }\end{array}$ & $\begin{array}{l}\text { Adult }(15+) \\
\text { population }\end{array}$ & \\
\hline \multicolumn{5}{|l|}{ A. Manufactures/primary } \\
\hline 1985 levels & 1.06 & -0.24 & 0.13 & 0.57 \\
\hline 2014 levels & 1.68 & -0.43 & {$[0.01]$} & 0.57 \\
\hline Change on 1985 level & {$[0.03]$} & -0.23 & $\{-0.08\}$ & 0.26 \\
\hline \multicolumn{5}{|c|}{ B. Services/goods (manufactured plus primary) } \\
\hline 1985 levels & 0.39 & {$[-0.04]$} & {$[-0.02]$} & 0.31 \\
\hline 2014 levels & 0.88 & -0.13 & {$[-0.03]$} & 0.47 \\
\hline Change on 1985 level & 0.21 & -0.11 & {$[0.03]$} & 0.24 \\
\hline \multicolumn{5}{|c|}{ C. Manufactures/(primary plus services) } \\
\hline 1985 levels & 0.45 & -0.07 & 0.14 & 0.43 \\
\hline 2014 levels & 0.35 & {$[-0.05]$} & $\{0.10\}$ & 0.18 \\
\hline Change on 1985 level & -0.24 & {$[0.00]$} & {$[-0.03]$} & 0.09 \\
\hline
\end{tabular}

Notes: data as for figures 1-2 and table 4. Other notes as for table 2, except that all regressions are across 125 countries.

\subsection{Services/goods output}

The share of services in GDP exceeded 50\% in all regions in 2014 and is higher in regions with more education (table 4, third column), as well as in countries with more education (first two regressions in panel B of table 5). However, although services are on average more educationintensive than goods in all countries (as shown in the statistical Appendix), these correlations between the service share of GDP and the average level of education are largely unrelated to comparative advantage. Most services are still non-tradable, and their higher shares in more educated countries mainly reflect more demand for (and a higher relative price of) services in countries with higher levels of per capita income, with which schooling is correlated.

Between 1985 and 2014, the share of services in GDP rose in all but one region (table 4, final column) and in three-quarters of all countries. Across countries, changes in this share were positively related to per capita income growth, but this explains only $5 \%$ of the variance. More variance is explained by initial levels of schooling (positive) and land abundance (negative), as in the third regression in panel $\mathrm{B}$ of table $5 .{ }^{15} \mathrm{~A}$ possible explanation is that faster expansion of manufacturing in countries with higher skill/land ratios generated more demand for producer services (which contribute about a fifth of the domestic value added in manufactured exports: WTO 2014, figure C.11). This hypothesis is supported by a significant positive correlation (not reported) between changes over the period in the share of services in GDP and changes in the manufactured/primary output ratio.

\footnotetext{
${ }^{15}$ If growth of per capita income is added to the third regression in panel $\mathrm{B}$, its coefficient is insignificant because growth was related to endowments. The results are similar if all OECD and FSS countries are dropped.
} 


\subsection{Deindustrialization of output?}

A standard measure of industrialization is the share of manufacturing in GDP (table 4, columns 2 and 5). In land-abundant regions, the falls in the manufacturing share of goods output were reinforced by rises in the service share of GDP, causing them all to deindustrialize, though only slightly in MENA and Sub-Saharan Africa, which were the least industrialized regions at the outset. In the land-scarce regions, the rises in the manufacturing share of goods output were offset by rises in the service share: in three of these regions, manufacturing still rose as a share of GDP, but it fell in the land-scarce OECD, and also in China, which started with an unusually low service share (as did the FSS, where deindustrialization was greatest).

Across all countries, changes in the share of manufacturing in GDP (third regression in panel C of table 5) were unrelated to land abundance, whose negative effect on manufacturing's share of goods production (panel A) was offset by its positive effect on the goods share of GDP (the complement of its negative effect on the service share in panel B). If producer services used in manufacturing were included in the measure of 'industry', there would probably be a clearer relationship between land abundance and deindustrialization.

The world as a whole deindustrialized, as shown in the penultimate row of table 4 , but mainly as a result of declines in the OECD and FSS regions. ${ }^{16}$ In all developing regions combined - the world less the OECD and FSS - the share of manufacturing in GDP did not alter, as shown in the final row of table 4 (and as first reported by Haraguchi 2014, fig. 3A). If China were omitted from the calculation, however, this share would fall (from 18.7\% to $16.0 \%$ ), rather than staying constant. Similarly, although all developing regions together raised their share of world manufacturing output by 28 percentage points (from 19\% to 47\%, at current prices), 20 of these points are accounted for by China.

At constant prices, manufacturing's share of GDP fell only slightly in developed countries, and rose substantially for developing countries in aggregate (Haraguchi et al. 2016, figs. 5-D, 6-B). In the land-abundant developing group, the decline in Latin America's manufacturing share of GDP at constant prices was only 2-3 percentage points, and in MENA this share rose slightly, though the fall in Sub-Saharan Africa seems to have been no smaller than at current prices. ${ }^{17}$ In the landscarce developing countries of Asia, changes in the manufacturing share were more strongly positive at constant prices, particularly in China, where the fall in the relative price of manufactures was unusually large.

Manufacturing in developing countries became more concentrated on the larger and richer ones (Haraguchi et al. 2016). ${ }^{18}$ The unweighted average manufacturing share of GDP in developing countries in 2014, at $12.5 \%$, was far below the $20.3 \%$ share in table 4 (which is a GDP-weighted average), and more so than in 1985 (when the averages were $14.8 \%$ and $20.2 \%$ ). ${ }^{19}$ The increase in

\footnotetext{
${ }^{16}$ As reflected in the negative coefficient on schooling in the third regression in panel C of table 5.

${ }^{17}$ These statements are based on roughly comparable regional averages from World Development Indicators and the UN National Accounts Main Aggregates database. Rodrik (2016) points out that the decline in the world price of manufactures tended to depress manufacturing output and employment, but this effect acted in the same direction in all developing countries and regions, whether land scarce or land abundant.

${ }^{18}$ Across all countries, however, the manufacturing share of GDP became slightly less positively related to population size (table 5, panel C).

${ }^{19}$ The lower share of manufacturing in the unweighted average than in the weighted average is offset mainly by a higher primary share, not a higher service share.
} 
concentration largely reflects the rise of China, without which the gap between the weighted and unweighted averages shrinks slightly, rather than widening.

\section{Sectoral structure of employment}

Table 6 shows levels and changes in the broad sectoral structure of employment in each region. The manufacturing share is shown both in total and for 'formal' employment (in firms covered by industrial surveys). There are notable differences among developing regions in the share of manufacturing employment that is formal: in 2014, it averaged almost 60\% in East Asia, but under $30 \%$ in South Asia and Sub-Saharan Africa, with Latin America and MENA in between.

Table 6: Employment by broad sector, 2014 levels and 1985-2014 changes

\begin{tabular}{|c|c|c|c|c|c|c|c|}
\hline & \multicolumn{4}{|c|}{$\begin{array}{c}\text { Shares of total } 2014 \\
(\%)\end{array}$} & \multicolumn{3}{|c|}{$\begin{array}{l}\text { Changes 1985-2014 } \\
\text { (Percentage points) }\end{array}$} \\
\hline & \multirow[t]{2}{*}{ Primary } & \multicolumn{2}{|c|}{ Manufacturing } & \multirow[t]{2}{*}{ Services } & \multirow{2}{*}{$\begin{array}{r}\text { All } \\
\text { manuf'g }\end{array}$} & \multirow{2}{*}{$\begin{array}{l}\text { Formal } \\
\text { manuf'g }\end{array}$} & \multirow[t]{2}{*}{ Services } \\
\hline & & All & Formal & & & & \\
\hline \multicolumn{8}{|l|}{ Land-scarce regions } \\
\hline Land-scarce OECD & 3.6 & 14.5 & 11.7 & 81.8 & -9.0 & -7.0 & 14.5 \\
\hline Other East Asia & 36.0 & 13.2 & 7.6 & 50.9 & 1.3 & 1.1 & 17.1 \\
\hline China & 33.6 & 18.2 & 10.7 & 48.2 & 3.4 & 5.5 & 26.8 \\
\hline India & 57.1 & 10.5 & 2.7 & 32.4 & 0.9 & 0.0 & 12.8 \\
\hline Other South Asia & 55.6 & 14.5 & 4.6 & 29.9 & 3.6 & 2.7 & -0.9 \\
\hline \multicolumn{8}{|l|}{ Land-abundant regions } \\
\hline Land-abundant OECD & 2.3 & 9.5 & 7.8 & 88.2 & -7.9 & -8.1 & 9.5 \\
\hline Former Soviet sphere & 20.4 & 15.7 & 10.4 & 63.9 & -12.3 & -14.7 & 17.6 \\
\hline Latin America & 16.7 & 13.0 & 6.2 & 70.2 & -2.0 & -1.1 & 17.6 \\
\hline Middle East \& N Africa & 18.5 & 12.5 & 6.0 & 69.0 & -0.9 & -0.5 & 16.3 \\
\hline Sub-Saharan Africa & 63.8 & 6.1 & 1.7 & 30.2 & 1.2 & -0.3 & 3.8 \\
\hline World & 34.6 & 13.3 & 7.2 & 52.1 & -2.0 & -1.8 & 14.4 \\
\hline Developing countries & 41.0 & 13.3 & 6.4 & 45.7 & 1.1 & 1.7 & 17.4 \\
\hline
\end{tabular}

Notes: 'Services' is all sectors except primary (agriculture plus mining) and manufacturing. 'Formal' refers to firms that meet the minimum size or registration criteria for inclusion in official surveys. 'Developing countries' exclude both OECD regions and FSS. '2014' is most recent available year. Data mainly from employment database of Haraguchi et al. (2016), supplemented for mining and for 20 missing countries from ILO WESO database. For formal manufacturing employment, data from UNIDO database for years closest to 1985 and 2014. Further details of sources and calculations are in the statistical Appendix, including discussion of the widely varying estimates of manufacturing employment in China.

\subsection{Manufactured/primary employment}

Within each land-abundance group, the primary share of employment in 2014 tends to be lower in regions with more schooling (table 6 , first column). This relationship is largely a reflection of the modernization of agriculture in the course of development, which greatly raises its labour productivity relative to that of other sectors. As a result, the positive coefficients on schooling in the cross-country regressions for the manufacturing/primary employment ratio in panels A1 and A2 of table 7, though they are partly due to the higher skill intensity of manufacturing than of primary production, are much larger than in the corresponding output regressions (in table 5), especially for formal employment. 
Like the corresponding export and output ratios, the manufacturing/primary employment ratio tends to be lower in countries with more land per worker, but the statistical significance of this relationship is not robust to the omission of outliers and East Asian countries (for either formal or all manufacturing employment), and there is even less relationship with country size. As in the output regressions, R-squared does not rise between 1985 and 2014.

Table 7: Sectoral employment ratios regressed on endowment ratios

\begin{tabular}{|c|c|c|c|c|c|}
\hline \multirow[b]{2}{*}{$\begin{array}{l}\text { Dependent variable \& } \\
\text { specification }\end{array}$} & \multicolumn{4}{|c|}{ Coefficients on independent variables } & \multirow[b]{2}{*}{ R-squared } \\
\hline & $\begin{array}{l}\text { Av. adult yrs of } \\
\text { schooling }\end{array}$ & $\begin{array}{l}\text { Schooling } \\
\text { quadratic }\end{array}$ & $\begin{array}{l}\text { Square } \mathrm{km} \text { of } \\
\text { land per adult }\end{array}$ & $\begin{array}{l}\text { Adult }(15+) \\
\text { population }\end{array}$ & \\
\hline \multicolumn{6}{|c|}{ A1. All manufacturing/primary } \\
\hline 1985 levels & 1.96 & & $\{-0.21\}$ & {$[0.04]$} & 0.66 \\
\hline 2014 levels & 2.80 & & $\{-0.18\}$ & {$[0.06]$} & 0.67 \\
\hline Change on 1985 level & 1.33 & -0.46 & {$[-0.06]$} & $\{0.08\}$ & 0.11 \\
\hline Labour intensity change & 1.80 & -0.63 & 0.15 & 0.16 & 0.22 \\
\hline \multicolumn{6}{|c|}{ A2. Formal manufacturing/primary } \\
\hline 1985 levels & 2.89 & & $\{-0.24\}$ & {$[-0.02]$} & 0.67 \\
\hline 2014 levels & 4.45 & & $\{-0.23\}$ & {$[-0.07]$} & 0.68 \\
\hline Change on 1985 level & 2.08 & -0.66 & {$[-0.05]$} & {$[0.06]$} & 0.14 \\
\hline Labour intensity change & 1.88 & -0.62 & 0.22 & $\{0.12\}$ & 0.26 \\
\hline \multicolumn{6}{|c|}{ B. Services/goods (manufactured plus primary) } \\
\hline 1985 levels & 1.15 & & {$[0.05]$} & {$[-0.06]$} & 0.46 \\
\hline 2014 levels & 1.86 & & {$[0.00]$} & {$[-0.07]$} & 0.59 \\
\hline Change on 1985 level & 0.11 & & $\{-0.07\}$ & {$[0.02]$} & 0.13 \\
\hline Labour intensity change & {$[-0.09]$} & & [0.04] & {$[-0.01]$} & 0.04 \\
\hline \multicolumn{6}{|c|}{ C1. All manufacturing/(primary plus services) } \\
\hline 1985 levels & 1.11 & & -0.13 & 0.10 & 0.64 \\
\hline 2014 levels & 1.03 & & {$[-0.07]$} & 0.13 & 0.43 \\
\hline Change on 1985 level & 1.08 & -0.53 & {$[0.00]$} & {$[0.05]$} & 0.34 \\
\hline Labour intensity change & 1.20 & -0.47 & {$[0.04]$} & 0.10 & 0.14 \\
\hline \multicolumn{6}{|c|}{ C2. Formal manufacturing/(primary plus services) } \\
\hline 1985 levels & 1.80 & & -0.14 & {$[0.04]$} & 0.70 \\
\hline 2014 levels & 2.28 & & {$[-0.06]$} & {$[0.02]$} & 0.54 \\
\hline Change on 1985 level & 1.87 & -0.74 & {$[0.04]$} & {$[0.04]$} & 0.20 \\
\hline Labour intensity change & $\{1.16\}$ & -0.43 & {$[0.03]$} & {$[0.06]$} & 0.09 \\
\hline
\end{tabular}

Notes: data as for figures 1-2 and table 6. Other notes as for table 2, except:

1. Regressions are across 125 countries, apart from (i) for formal manufacturing (82 countries, due to missing data) and (ii) for the third and fourth regressions in panels $A 1$ and $C 1$, which omit the 14 countries listed in the notes for table 2 with outlying values of independent variables (the 9 countries with very low schooling obscure the quadratic relationships).

2. 'Labour intensity change' specification regresses the 1985-2014 change in the relative labour intensity of the sectors concerned on 1985 endowments, with 'labour intensity' defined as the ratio of a sector's share of employment to its share of GDP. The formal manufacturing labour intensity calculations relate formal manufacturing employment to all manufacturing output (but even in countries with much informal manufacturing employment, most of the manufacturing output is produced by formal sector firms, whose labour productivity is much higher). 
Changes in manufactured/primary employment ratios over the period were weakly negatively related across countries to land abundance and weakly positively related to country size (third regressions of panels A1 and A2). But there is a strong non-linear relationship with the initial level of schooling: changes in the manufacturing/primary employment ratio are more positive in bettereducated countries only up to a point, beyond which the effect reverses. ${ }^{20}$

This non-linearity arises not from changes in the manufactured/primary output ratio (which were unrelated to schooling), but from changes in the labour intensity of manufacturing relative to primary production (fourth regressions in panels A1 and A2). The negative quadratic terms capture the global restructuring of manufacturing during this period: the growth of export-oriented manufacturing in developing countries (which was labour-intensive, but increased the relative labour intensity of manufacturing by pulling surplus labour out of agriculture), and the shift of manufacturing in developed countries from labour-intensive to skill-intensive activities. ${ }^{21}$

These regressions also reveal a positive relationship across countries between changes in the labour intensity of manufacturing relative to primary production during 1985-2014 and initial levels of land abundance. Since labour intensity (employment/output) is the inverse of labour productivity, this result implies that the deepening comparative disadvantage of land-abundant countries in manufacturing was associated with slower growth of output per worker in their manufacturing sectors, relative to their primary sectors, than in land-scarce countries.

\subsection{Services/goods employment}

The share of employment in services is higher in regions with more schooling (table 6 , fourth column), as it is also across countries (table 7, first two regressions in panel B), mainly because of the rise in relative demand for services and the fall in relative labour productivity in services in the normal course of development. Service sector employment shares are higher in the land-abundant regions, but only because they are richer: after controlling for schooling and country size, in panel B of table 7, there is no cross-country relationship between land abundance and the service share of employment.

During 1985-2014, the service share of employment rose in almost every region and in 93\% of countries. These rises tended to be larger in more educated countries and smaller in more landabundant countries (third regression in panel B). ${ }^{22}$ This pattern paralleled that of changes in the service share of output (third regression in panel B of table 5), since changes in the relative labour intensity of services and goods production were not significantly related to endowments and country size (fourth regression in panel B of table 7).

\subsection{Deindustrialization of employment?}

Manufacturing's share of total employment fell substantially during the period in both OECD regions (table 6, penultimate two columns). Manufacturing employment fell by even more in the

\footnotetext{
${ }^{20}$ The inflection point is a non-existent 18 average years of schooling for the all-manufacturing regression and 23 years for the formal manufacturing one.

${ }^{21}$ The level of the manufacturing/primary labour intensity ratio is not related quadratically to schooling in 1985, but becomes quadratic in 2014, though significantly so only in the all-manufacturing regression (whose fit also improves).

${ }^{22}$ As with the corresponding shares of GDP, changes in the service share of employment were also significantly positively correlated with changes in the manufactured/primary employment ratio.
} 
FSS region, especially formal employment, as a result of the large fall in manufacturing's output share (table 4), combined with job-shedding in formerly state-owned enterprises.

Manufacturing's share of employment rose in all the land-scarce developing regions, except for formal manufacturing in India, where employment stagnated because of a shift away from labourintensive activities. ${ }^{23}$ The largest share increase was for formal manufacturing in China, despite state enterprise job-shedding there, too (though estimates of manufacturing employment in China vary widely, as discussed in the statistical Appendix).

In all three land-abundant developing regions, manufacturing's share of employment fell, except for a (doubtful) rise for all manufacturing in Sub-Saharan Africa. ${ }^{24}$ The fall in the manufacturing employment share in Latin America is much smaller than the fall in its manufacturing output share (table 4), because job losses in import-competing sectors that shrank were offset by growth of labour-intensive manufactured exports from countries close to the US, especially Mexico. ${ }^{25}$

Across all countries, changes in manufacturing's share of employment were unrelated to land abundance (table 7, third regressions in panels C1 and C2), as was true also of the changes in its share of output (in table 5). But the non-linear relationship of the manufacturing/primary employment ratio with the initial level of schooling exists also for the manufacturing/all other employment ratio, again reflecting a non-linear pattern of changes in labour intensity (fourth regressions in panels $\mathrm{C} 1$ and $\mathrm{C} 2)^{26}$

World employment deindustrialized slightly during 1985-2015 (penultimate row of table 6), but both the formal and the all-manufacturing employment shares rose in developing countries as a whole (last row of table 6 and as first reported by Haraguchi 2014). The small changes in table 6 fail to convey the scale of reallocation among regions, especially of formal employment in manufacturing, whose global total in 2014 was about 225 million workers, up by 50 million during the period. The OECD's share fell by 15 percentage points, and that of the FSS by 18 points. East Asia's share rose by 25 points (four-fifths of it in China), South Asia's by 4 points, and that of the three land-abundant developing regions together also by 4 points.

Despite concerns about 'premature deindustrialisation' (Felipe et al. 2016; Rodrik 2016), the results above show (as in Haraguchi et al. 2016) that for developing countries as a whole manufacturing's share of employment rose, as did its share of output at constant prices. But the rises were mainly in land-scarce developing regions, while land-abundant regions deindustrialized (as found also by McMillan et al. 2014 and Rodrik 2016).

Manufacturing employment became increasingly concentrated on larger developing countries, too, though less so than manufacturing output (Haraguchi et al. 2016, figures 8-10). For both all and formal manufacturing, the unweighted average shares of employment in developing countries fell

\footnotetext{
${ }^{23}$ This shift, reflected in the export shares in table 3, is documented by Sen and Das (2015).

${ }^{24}$ If calculated with ILO WESO data, the all-manufacturing share in Sub-Saharan Africa would also fall.

${ }^{25}$ Mexico's share of Latin America's gross manufactured exports increased during 1985-2014 by 16 percentage points, to $52 \%$, on the basis of its lower skill/labour ratio than the US and as a result of its trade and co-operation costs with its large neighbour being reduced by NAFTA. Mexico's formal manufacturing employment rose, too, as a share both of the Latin American total and of all employment in Mexico. The 1985-2014 drop in the processed primary share of Latin America's manufactured exports in table 3 also mainly reflects the expansion of Mexico's manufactured exports, $94 \%$ of which in 2014 were narrow.

26 The all-manufacturing share of employment is positively related to adult population size, but the formal manufacturing share is not, because the data for formal employment omit many small poor countries.
} 
slightly between 1985 and 2014, while the weighted averages in table 6 rose. The difference is mainly China, omitting which would cause the weighted all-manufacturing share for developing countries in table 6 to rise by only 0.6 (rather than 1.1) percentage points and the formal share to remain almost constant (rather than rising by 1.7 percentage points).

\section{$7 \quad$ What drove structural change?}

At both the start and the end of the period, as shown in the three previous sections, the sectoral composition of exports, output, and employment varied across regions and countries with their factor endowments in ways consistent with HO theory. During the rapid globalization of 19852015, however, sectoral structures also changed significantly. This section asks why, focusing on the goods sectors (since service share changes were driven mainly by domestic forces).

Table 8: Manufacturing share changes, 1985-2014 (percentage points)

\begin{tabular}{lrrc}
\hline & Exports & Output & Employment \\
Land-scarce regions & & & \\
Land-scarce OECD & 1.1 & 4.5 & -7.0 \\
Other East Asia & 13.4 & 14.1 & 1.1 \\
China & 45.5 & 15.8 & 5.5 \\
India & 16.1 & 15.0 & 0.0 \\
Other South Asia & 22.3 & 12.8 & 2.7 \\
& & & \\
Land-abundant regions & & & \\
Land-abundant OECD & -5.8 & -8.5 & -8.1 \\
Former Soviet sphere & -12.5 & -5.0 & -14.7 \\
Latin America & -1.1 & -12.5 & -1.1 \\
Middle East \& N Africa & -10.8 & -2.0 & -0.5 \\
Sub-Saharan Africa & -14.2 & -1.5 & -0.3 \\
\hline
\end{tabular}

Notes: data from tables 1, 4, and 6. For exports and output, the shares are of manufacturing in goods (manufacturing + primary). For employment, the shares are of formal manufacturing in economy-wide employment.

The pattern of change across regions is summarized in table 8 for manufacturing exports, output, and employment. Its most striking feature is that in the land-abundant regions all the numbers are negative, while in the land-scarce regions all but two are positive. One exception is the lack of change in formal employment in India, despite big rises in export and output shares, reflecting its failure to expand labour-intensive manufactured exports. The other is the fall in manufacturing employment in the land-scarce OECD (as also in the land-abundant OECD), reflecting the shift in developed countries from labour-intensive to skill-intensive activities.

The two land-scarce regions with the largest rises in the employment share of manufacturing (China and Other South Asia) were also the ones with the largest rises in manufactured export shares. In Latin America, similarly, neither manufacturing's share of employment nor its share of exports declined much, despite a big fall in its output share, because of the growth of labourintensive manufactured exports to the US. Manufacturing employment shares in Sub-Saharan Africa and MENA declined even less, despite big falls in their manufactured export shares, but only because there was so little manufacturing employment initially.

A standard HO explanation of these changes would be that reduced barriers to trade caused the sectoral structures of countries to become more closely aligned with their factor endowments, and 
in important respects the evidence fits this explanation. Almost all countries became more open to trade, land-abundant countries became more specialized in primary products relative to manufactures, and skill-abundant countries became more specialized in skill-intensive sorts of manufacturing. ${ }^{27}$ This cannot be the whole story, however, for two related reasons.

First, the closeness of fit between sectoral structures and endowments did not always improve. The R-squareds of the cross-country regressions are higher in 2014 than in 1985 for most of the export structure ratios, and especially for the skill-intensive/labour-intensive manufactured export ratio. But they are no higher for the output or employment structure ratios, though these are limited to the manufactured/primary dimension for lack of data on the skill composition of manufacturing output and employment.

Second, some of the changes in sectoral structure occurred because of shifts in the relationship with endowments: the slopes of the cross-country regressions became steeper. This was clearly so in the land/labour dimension, with an apparent strengthening of the comparative advantage of land-scarce countries in manufacturing. The increases in the manufacturing share of exports, output, and employment in land-scarce regions, and the decreases in land-abundant regions, did not arise just from reduced discrepancies between actual outcomes and the outcomes that would be predicted from endowments, but also from shifts in the predicted outcomes.

In the skill/labour dimension, the evidence is harder to interpret because, as noted earlier, the changes in slope coefficients partly reflect a probably spurious improvement in the educational levels of poorer countries. However, the rise between 1985 and 2014 in the skill coefficient is particularly large in the skill-intensive/labour-intensive manufactured export regression, which implies a strengthening of the comparative advantage of skill-abundant countries in more skillintensive manufacturing, in addition to the reduction of discrepancies between the actual and predicted skill mix of manufactured exports implied by the rise in R-squared. This inference is supported by the emergence during the period of an inverse quadratic relationship across countries between level of schooling and the relative labour intensity of manufacturing. ${ }^{28}$

These facts suggest that the shifts in sectoral structure during this period were driven not only by falls in trade costs, but also by falls in 'co-operation costs'. More specifically, reductions in the cost of international business travel and communication and improvements in management systems enabled highly-skilled workers in developed countries to co-operate more extensively and effectively with workers in developing countries. Some of the increase in co-operation was within growing multinational companies, but much was in the form of contractual relationships among independent firms linked together in an ever-expanding network of global value chains (and by a large increase in trade in parts and components). ${ }^{29}$

The reduction of co-operation costs thus permitted an endowment-biased international transfer of technology (in design and marketing, as well as in production). More concretely, it enabled know-how in labour-intensive manufacturing to flow from skill-abundant developed countries to

\footnotetext{
${ }^{27}$ A better test than is attempted in this paper would be to relate changes over the period for individual countries in the relationship between their sectoral structures and their endowments to changes in their trade barriers.

${ }^{28}$ This quadratic relationship in levels emerges both for all manufacturing and for formal manufacturing, relative both to primary production and to all other sectors. However, the negative quadratic coefficients in 2014 are significant, and the fit of the quadratic regressions is better in 2014 than in 1985, only for all manufacturing (the data for which cover more countries: 111, compared to 82 for formal manufacturing).

${ }^{29}$ WTO (2014, Part IIC) reviews the evidence on global value chains. The term 'co-operation costs' originates in Anderson et al. (2006). Related theory is in Markusen (2001) and Baldwin and Robert-Nicoud (2014).
} 
skill-scarce developing countries, and within the latter group mainly to land-scarce countries, whose endowment mix offered the best prospects of putting this know-how to profitable use in producing exports for the world market. ${ }^{30}$

Consistent with this inference is the rise in the manufacturing/primary output per worker ratio in land-scarce countries relative to land-abundant countries. Since output is measured by value added, this shift reflects a relative increase in some combination of skill per worker, capital per worker, and returns to skill and capital in manufacturing, as expected from the introduction of better technology. The technology-transfer explanation also fits with Rodrik's (2013) finding of unconditional convergence in formal sector manufacturing labour productivity.

The endowment bias of the technology transfer can explain both why comparative advantage in manufacturing shifted further towards land-scarce countries and why comparative advantage in less skill-intensive manufacturing shifted further towards skill-scarce countries. Moreover, although most of the technology transfer was in narrow manufacturing, it probably spilled into other industrial sectors and could help to explain why land-abundant countries apparently lost comparative advantage in primary processing, too. ${ }^{31}$ This transfer of technology also helps to explain why land-scarce developing countries grew faster than land-abundant ones (as will be documented later), by raising total factor productivity (TFP) and stimulating investment, as well as by reallocating resources to more productive sectors (McMillan et al. 2014).

Exactly what happened varied a lot among countries and regions, depending on the initial levels of their trade costs and co-operation costs and on how much each of these sorts of costs declined (the possible combinations of levels and changes are analysed in Wood 2002). And of course, some skill-scarce, land-scarce countries were excluded from the transfer by, for example, lack of infrastructure, weak institutions, or civil war. Outcomes also differed for reasons unrelated to trade costs or co-operation costs, which would need to be taken into account in analysing the experiences of particular countries or regions. ${ }^{32}$ But the augmented HO framework, including cooperation costs as well as trade costs, provides a clear and plausible broad-brush explanation of the worldwide pattern of structural change during 1985-2015.

How much of this 'worldwide' pattern is attributable simply to China? As noted earlier, China accounts for much of the rise in the developing-country share of global manufacturing $-70 \%$ for current-price output and 60\% for formal employment. Omitting China makes significant but smaller differences to changes in the sectoral structure of developing countries in aggregate: the share of manufacturing in GDP falls by 3 percentage points during 1985-2015, rather than remaining constant; and the share of formal manufacturing in employment stays constant rather than rising by 2 percentage points. Omitting China (which is only one observation) has almost no

\footnotetext{
${ }^{30}$ The global pattern of comparative advantage at both the start and the end of the period may also be a result partly of earlier endowment-biased technology transfers. Opportunities for profitable exporting caused the transfer of modern agricultural and mining technologies to land-abundant countries, which, for those that were unsuitable for European settlement, amplified their endowment-related comparative advantage in primary production. In landabundant countries that were settled by Europeans, manufacturing technology was also transferred and hence the effect on comparative advantage was more neutral (Wood and Jordan 2000).

${ }^{31}$ Owens and Wood (1997) note the similarities between primary processing and other sorts of manufacturing. Davis (2010) finds that a country's comparative advantage in primary processing depends on the extent of its narrow manufacturing activity as well as on its endowments of skill and land.

${ }^{32}$ Another possible cause of the transfer of manufacturing technology to developing countries was the tightening of environmental policies in developed countries. Econometric evidence on this hypothesis is limited and mixed (Copeland 2013), and the industries that most conspicuously relocated to developing countries were not the usual 'dirty' ones, but for example garments, footwear, and the assembly of electrical equipment.
} 
effect on the regressions, which are usually in line with the regional aggregate results. How sectoral shares changed in relation to endowments was thus common to most countries.

China's growth, however, was not just an addition to global totals: structural change in other countries over this period would have been different if it had remained an autarkic non-market economy. China's opening to trade effectively lowered the global land/labour ratio and raised the share of workers with a basic education in the global labour force, shifting the comparative advantage of other developing countries from manufacturing to primary production, though in most cases not by much (Wood and Mayer 2011). Had China remained closed, in short, other developing countries in aggregate would have become more industrialized.

\section{What happened to factor prices?}

HO theory makes predictions about the effects of globalization not only on sectoral structure but also on factor prices. A proper analysis lies beyond the scope of this paper, but a brief look at factor price movements is worthwhile, partly as a check on the preceding explanation of structural change (since, in theory, quantity and price movements are related) and partly because of their social and political importance.

The standard HO prediction is that reduction of barriers to trade benefits a country's abundant factors and hurts its scarce factors. Thus land rents should have risen relative to wages in landabundant countries and fallen in land-scarce ones, while skilled workers should have gained relative to unskilled workers in skill-abundant countries and lost in skill-scarce ones. Lack of data on land rents makes it impossible to assess the accuracy of the first of these predictions. ${ }^{33}$ Comparable data on wages across countries and periods are also scarce, but there are enough for an assessment of the second prediction.

In the skill-abundant OECD countries during 1985-2015, skilled workers, as predicted, usually gained relative to unskilled workers, though the role of globalisation is disputed. ${ }^{34}$ In other regions, outcomes varied among countries and periods, but again skilled workers usually gained relative to unskilled workers. ${ }^{35}$ These relative gains of skilled workers in developing countries were sometimes consistent with the HO prediction: some developing (as well as FSS) countries are of above-worldaverage skill abundance, and in land-scarce countries expansion of formal manufacturing raised the wages of workers with a basic education relative to workers whose lack of education tied them to agriculture and the informal sector. But in largely literate land-scarce developing countries the relative rise in skilled wages conflicted with the HO prediction.

There were two other worldwide distributional changes for which standard HO theory provides no explanation. One was large rises in incomes at the very top of the distributions in developed countries and some developing countries (Atkinson and Piketty 2010). The other was a large rise in the share of non-wage income in GDP in most countries for which relevant data exist, despite a secular decline over this period in interest rates (Timmer et al. 2014).

\footnotetext{
33 Potential sources of data explored include the Global Trade Analysis Project, GTAP (rent share of sectoral value added), the International Comparison Program, ICP (housing rents), and World Development Indicators (resource rents).

${ }^{34}$ For example, Cline (1997), Wood (1998), Edwards and Lawrence (2013), Autor et al. (2016).

35 The literature is reviewed in Anderson (2005), Goldberg and Pavcnik (2007), and Harrison et al. (2011).
} 
The fall in co-operation costs that contributed to structural change by transferring manufacturing know-how from developed countries helps to explain these distributional inconsistencies, too. It raised the relative wages of skilled workers in land-scarce developing countries where the new manufacturing activities, though not skill-intensive by developed-country standards, were more skill-intensive than in the rest of their economies (Wood 2002). These transfers also generated huge gains for those with the relevant know-how, both people and firms, contributing to the rises in top incomes and in the non-wage share of GDP (Anderson et al. 2006).

Of greatest practical significance, however, was the factor price change that was most clearly consistent with HO. Despite an explicit warning in Wood (1994), governments in OECD countries took insufficient action to redress the worsening position of less-skilled workers, which eventually caused a political backlash against globalization.

\section{$9 \quad$ Prospects and policy options}

Between 1985 and 2015, the endowment-related pattern of sectoral specialization among the world's countries and regions intensified, because of falls in trade costs and co-operation costs. Developed-country manufacturing became more skill-intensive. Developing countries in total became more industrialized and increased their share of world manufacturing, but this progress was concentrated in land-scarce East Asia and above all China. In land-abundant developing regions, industrialization stagnated or declined, and in land-scarce South Asia industrialization was held back by low literacy and weak infrastructure.

How might sectoral structures evolve in the future, and what are the implications for policies to accelerate development? The trajectory of the world economy is now particularly uncertain, because of political turbulence, controversy over decarbonization and robotization (Ford 2015), and concern about secular stagnation (Mayer 2016). HO theory, however, offers a framework for analysis in which sectoral structure depends on only three things: variation among countries in endowments of immobile factors (skill, land, and labour); variation among goods in immobilefactor intensities; and the height of barriers to international transactions. Changes in these things tend to cause well-defined changes in sectoral structures.

A change in the height of barriers in this model shifts the world economy from one structural equilibrium to another, with no further movement after the period of adjustment. The upward trend since 1985 in the world total ratio of trade to GDP, following stagnation during 1975-85, ceased after 2011 (WTO 2015), which might mean that global structural adjustment to the falls in barriers since 1985 had been completed. ${ }^{36}$

The political backlash could reverse the fall in policy barriers, as evidenced by US withdrawal from the Trans-Pacific Partnership and Transatlantic Trade and Investment Partnership, albeit probably by less than after the first wave of globalization in the nineteenth century (Williamson 1998). However, transport and communications technologies will continue to improve, a wider range of services will become tradable, and there remains huge scope for reducing non-policy barriers in the many developing countries without adequate infrastructure. Global economic structures will thus continue to be strongly specialized in accordance with endowments, and on balance are likely to move further in this direction, though perhaps not soon.

\footnotetext{
${ }^{36}$ Though the trade slowdown also had other causes, analysed in IMF (2016, ch. 2).
} 
The sectoral and product details of endowment-based specialization will inevitably change, not least as a result of robotization. Like other traded capital goods, robots will be available to all countries at much the same price and so in themselves cannot give a country an advantage over any other country. Robots could, however, alter the global pattern of comparative advantage in particular goods by altering their relative immobile-factor intensities. For example, if skilled workers with robots could make shoes more efficiently than unskilled workers, comparative advantage in shoe production would shift from skill-scarce to skill-abundant countries. And to the extent that robotization shrinks differences in skill intensity among goods, it will also tend to shrink the amount of skill-endowment-based trade among countries.

The global pattern of comparative advantage will also alter because of changes in relative factor endowments, slowly for regions but faster for individual countries. Of particular importance over the next decade or so will be a rise in the relative skill abundance of China, following the upward move of South Korea and Taiwan over the past couple of decades. The composition of China's manufacturing will thus shift away from labour-intensive goods and activities and into more skillintensive ones, as has already started to happen.

This structural shift will bring China into direct competition with the OECD countries (which are already specialized in skill-intensive manufacturing) and tend to lower the world prices of skillintensive manufactures relative to those of labour-intensive manufactures, contrary to the trend of the past three decades (Fu et al. 2012). Such a change in world prices would lower the wages of the mainly skilled OECD workforce (and those of skilled workers relative to unskilled workers in all countries). This price shift and the associated shrinkage of manufacturing output in OECD countries, however, will be mitigated or perhaps even reversed by the high income elasticity of demand for skill-intensive goods (Caron et al. 2014).

Other land-scarce developing countries will occupy the labour-intensive manufacturing space vacated by China (Wood and Mayer 2011). Their sectoral shares of manufacturing will rise, relative to those of primary activities, for both output and employment, particularly formal employment (and, insofar as the relative world price of labour-intensive manufactures rises or at least ceases to fall, the relative earnings of their unskilled workers will benefit). It remains to be seen whether India's push to make up for lost time in basic education, infrastructure, and other policies (Wood and Calandrino 2000) will enable it to take over most of China's former manufacturing, or whether most will go to other countries, probably mainly in South Asia and East Asia, as well as land-scarce parts of Sub-Saharan Africa.

Slower population growth in richer than poorer countries will continue to bring their land/labour ratios closer together (figure 2), and by 2100 the huge gap in this ratio between Africa and Asia is projected to fall by two-thirds (UN, 2015, table 1). But variation among countries in land/labour ratios will remain a basic feature of the world economy, as it has been for the past millennium (Wood 2003, table 2), and so too will the resulting differences in sectoral structure between landscarce and land-abundant countries documented in this paper.

By promoting specialization, international trade amplifies these differences and causes land-scarce and land-abundant countries to follow different development paths as they accumulate skills and capital (Wood 2003). In particular, a land-scarce country that is open to trade will go through a phase of specialization in labour-intensive narrow manufactures, while a land-abundant country is more likely to move into primary processing and not to export narrow manufactures until it achieves a higher level of skill per worker, by which time its comparative advantage within manufacturing will be in more skill-intensive goods. 
Figure 7: GDP per capita, 1985 and 2014 (thousand 2005 US dollars)

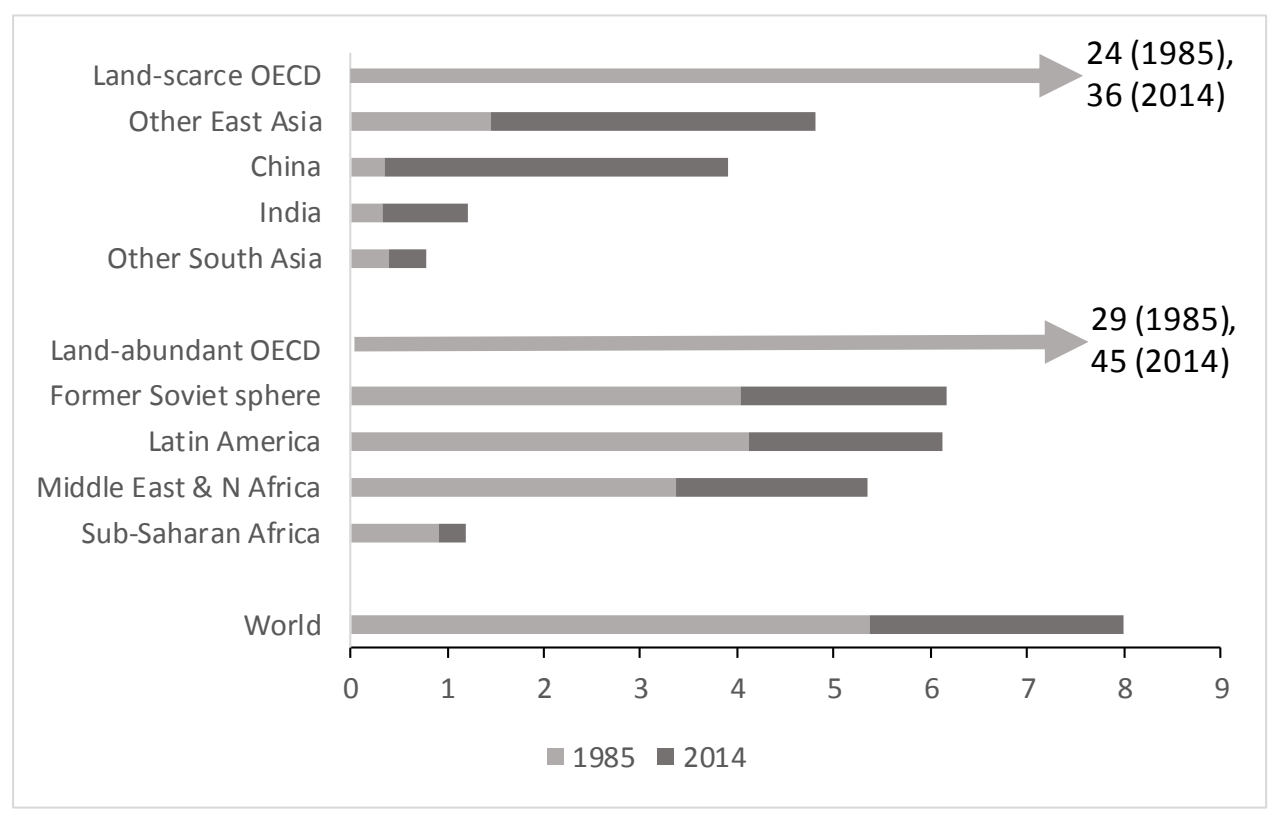

Notes: data from UN National Accounts Main Aggregates database. In the richest region (the land-abundant OECD), real GDP per capita grew by $1.6 \%$ per year on average between 1985 and 2014. This growth rate was exceeded in all the land-scarce developing regions (Other East Asia 4.2\%; China 8.7\%; India 4.7\%; Other South Asia 2.4\%), but not in any land-abundant region (FSS 1.5\%; Latin America 1.4\%; MENA 1.6\%; Sub-Saharan Africa $0.9 \%)$.

Land-scarce countries tend to be richer than land-abundant countries: the simple cross-country elasticity of per capita GDP with respect to land area per adult is about -0.2 , and statistically significant, in both 1985 and 2014. ${ }^{37}$ The inverse relationship disappears after controlling for average years of schooling, implying that land-abundant countries are poorer because they are less well educated. This is no coincidence: specialization in less skill-intensive primary sectors reduces the demand for education (Blanchard and Olney 2016). It is also a key reason why the quality of governance matters more for successful development in land-abundant countries than in landscarce countries (Mehlum et al. 2006).

The regional weighted averages in figure 7 give a different impression. In 1985, land-abundant regions tended to be richer than land-scarce regions, and this was still so in $2014 .{ }^{38}$ But faster per capita GDP growth in land-scarce developing regions narrowed the gap (and brought them all proportionally closer to the world's richest region, the land-abundant OECD, which did not happen for any land-abundant developing region). ${ }^{39}$ Pulling the other way, rapid growth in Asia contributed to a rise in the relative world price of primary products, which benefited land-abundant countries through an improvement in their terms of trade not reflected in these data, and will continue to do so in the future.

\footnotetext{
${ }^{37}$ This relationship explains very little of the variance of per capita income, but it is robust to the exclusion of countries with both unusually high and unusually low levels of land per adult.

38 This reversal of the cross-country pattern occurs partly because the land-abundant regions were initially more educated and partly because, among land-scarce countries, the richer ones tend to be smaller, while among landabundant countries, the richer ones tend to be bigger.

${ }^{39}$ Corresponding with the usual interpretation of the 'resource curse' (on which a concise literature review, and a different empirical perspective, is in Smith 2015), and also with the findings of McMillan et al. (2014).
} 
As figure 7 also shows, the average incomes of both land-abundant and land-scarce developing countries are still far below those of their OECD counterparts, and to attain developed-country income levels would require both groups to improve in many of the same respects. Even in the field of trade policy, best practice is much the same: reduce infrastructural and other non-policy barriers, assist exporters, avoid grossly distorting policy barriers, use sectoral industrial policies with extreme caution, and be alert to distributional effects, especially on poor people.

Some of the specifics of development policy, however, do differ between these two groups of countries (Wood 2003: 192-4). Land-abundant countries need to make more supply-side effort to increase schooling. They need more infrastructure per person, too, because of their lower population density. Their training and research should be more natural-resource-oriented, and they need to pay greater attention to reducing inequalities in the ownership of land and other assets. In all these respects, as in the areas where their priorities overlap, intelligent support from the international community can help both groups of countries.

\section{References}

Anderson, E. (2005). 'Openness and Inequality in Developing Countries: a Review of Theory and Recent Evidence'. World Development, 33(7): 1045-63.

Anderson, E., P. Tang, and A. Wood (2006). 'Globalisation, Co-operation Costs and Wage Inequalities'. Oxford Economic Papers, 58(4): 569-95.

Atkinson, A., and T. Piketty (2010). Top Incomes over the Twentieth Century: A Global Perspective. Oxford: Oxford University Press.

Autor, D., D. Dorn, and G. Hanson (2016). 'The China Shock: Learning from Labour Market Adjustment to Large Changes in Trade'. NBER Working Paper 21906. Cambridge, MA: NBER.

Baldwin, R., and F. Robert-Nicoud (2014). 'Trade-in-Goods and Trade-in-Tasks: An Integrating Framework'. Journal of International Economics, 92(1): 51-62.

Blanchard, E., and W. Olney (2016). 'Globalization and Human Capital Investment: Export Composition Drives Educational Attainment.' http://web.williams.edu/Economics/wp/OlneyExportsandEducation.pdf (accessed 5 September 2016).

Caron, J., T. Fally, and J. Markusen (2014). 'International Trade Puzzles: A Solution Linking Production and Preferences'. Quarterly Journal of Economics, 129(3): 1501-52.

Chor, D. (2010). 'Unpacking Sources of Comparative Advantage: A Quantitative Approach'. Journal of International Economics, 82(2): 152-67.

Cline, W. (1997). Trade and Income Distribution. Washington DC: Institute for International Economics.

Copeland, B. (2013). 'The Pollution Haven Hypothesis'. Lecture at University of Nottingham. https://www.nottingham.ac.uk/gep/news-events/public-lectures/nott-lec-int-econ/briancopeland-2013.aspx (accessed 1 October 2016).

Davis, G. (2010). 'Mongolia: Mineral Sector Strategic Analysis'. Unpublished report for UNIDO Division of Economics and Business, Colorado School of Mines.

Edwards, L., and R. Lawrence (2013). Rising Tide: Is Growth in Emerging Economies Good for the United States? Washington DC: Peterson Institute for International Economics. 
Felipe, J., A. Mehta, and C. Rhee (2016). 'Manufacturing Matters ... but It's the Jobs that Count'. Update of Working Paper 420, 2014. Manila: Asian Development Bank.

Ford, M. (2015). Rise of the Robots: Technology and the Threat of a Jobless Future. New York: Basic Books.

Fu, X., R. Kaplinsky, and J. Zhang (2012). 'The Impact of China on Low and Middle Income Countries' Export Prices in Industrial-Country Markets'. World Development, 40(8): 1483-98.

Goldberg P., and N. Pavcnik (2007). 'Distributional Effects of Globalisation in Developing Countries'. Journal of Economic Literature, XLV(1): 39-82.

Haraguchi, N. (2014). 'Patterns of Structural Change and Manufacturing Development'. Working Paper 07/2014. Vienna: Research, Statistics and Industrial Policy Branch, UNIDO.

Haraguchi, N., C. Cheng, and E. Smeets (2016). 'The Importance of Manufacturing in Economic Development: Has this Changed?' Working paper 1/2016. Vienna: Department of Policy Research and Statistics, UNIDO.

Harrison, A., J. McLaren, and M. McMillan (2011). 'Recent Perspectives on Trade and Inequality'. Annual Review of Economics, 3: 261-289.

IMF (2016). World Economic Outlook. October. Washington, DC: IMF.

Markusen, J. (2001). 'Contracts, Intellectual Property Rights, and Multinational Investment in Developing Countries'. Journal of International Economics, 53(1): 189-204.

Mayer, J. (2016). 'How Could the South Respond to Secular Stagnation in the North?'. The World Economy, forthcoming.

McMillan, M., D. Rodrik, and I. Verduzco-Gallo (2014). 'Globalisation, Structural Change and Productivity Growth, with an Update on Africa'. World Development, 63: 11-32.

Mehlum, H., K. Moene, and R. Torvik (2006). 'Institutions and the Resource Curse'. Economic Journal, 116: 1-20.

Owens, T., and A. Wood (1997). 'Export-Oriented Industrialisation through Primary Processing?' World Development, 25(9): 1453-70.

Pritchett, L. (2013). The Rebirth of Education: Schooling Ain't Learning. Washington, DC: Centre for Global Development.

Rodrik, D. (2013). 'Unconditional Convergence in Manufacturing' Quarterly Journal of Economics, 128(1): 165-204.

Rodrik, D. (2016). 'Premature Deindustrialisation'. Journal of Economic Growth, 21(1): 1-33.

Romalis, J. (2004). 'Factor Proportions and the Structure of Commodity Trade'. American Economic Review, 94(1): 67-97.

Rotunno, L., and A. Wood (2016). 'Wage Inequality and Skill Supplies in a Globalised World'. http://www.amse-aixmarseille.fr/sites/default/files/_dt/2012/wp_2016_-_nr_34.pdf (accessed 15 September 2016).

Sen, K., and D. Das (2015). 'Where Have all the Workers Gone? Puzzle of Declining Labour Intensity in Organised Indian Manufacturing'. Economic and Political Weekly, L(23): 108-15.

Smith, B. (2015). 'The Resource Curse Exorcised: Evidence from a Panel of Countries'. Journal of Development Economics, 116: 57-73.

Timmer, M., A. Erumban, B. Los, R. Stehrer, and G. de Vries (2014). 'Slicing up Global Value Chains'. Journal of Economic Perspectives, 28(2): 99-118.

UN (2015). World Population Prospects: Key Findings and Advance Tables. New York: UN. 
Williamson, J. (1998). 'Globalisation, Labour Markets and Policy Backlash in the Past'. Journal of Economic Perspectives, 12(4): 51-72.

Wood, A. (1994). North-South Trade, Employment and Inequality: Changing Fortunes in a Skill-Driven World. Oxford: Clarendon Press.

Wood, A. (1998). 'Globalisation and the Rise in Labour Market Inequalities'. Economic Journal, 108: 1463-82.

Wood, A (2002). 'Globalisation and Wage Inequalities: A Synthesis of Three Theories. Review of World Economics, 138(1): 54-82.

Wood, A. (2003). 'Could Africa Be like America?'. In B. Pleskovic and N. Stern (eds), Annual Bank Conference on Development Economics 2003. World Bank and Oxford University Press.

Wood, A (2009). 'Heckscher-Ohlin in Theory and Reality'. In P. Arestis and J. Eatwell (eds), Issues in Economic Development and Globalisation. London: Palgrave Macmillan.

Wood, A., and M. Calandrino (2000). When the Other Giant Awakens: Trade and Human Resources in India'. Economic and Political Weekly, XXXV(52-53): 4677-94.

Wood, A., and K. Jordan (2000). 'Why Does Zimbabwe Export Manufactures, and Uganda not?' Journal of Development Studies, 37(2): 91-116.

Wood, A. and J. Mayer (2011). 'Has China De-industrialised Other Developing Countries?' Review of World Economics, 147(2): 325-50.

WTO (2014). World Trade Report 2014. Geneva: WTO.

WTO (2015). International Trade Statistics 2015. Geneva: WTO. 